\title{
Osteology and relationships of Luxembourgichthys ("Pholidophorus") friedeni gen. nov. (Teleostei, "Pholidophoriformes") from the Lower Jurassic of Belgium and the Grand Duchy of Luxembourg
}

\author{
Louis TAVERNE ${ }^{*} \&$ Etienne STEURBAUT ${ }^{2}$
}

\author{
${ }^{1}$ Royal Belgian Institute of Natural Sciences (RBINS), OD Earth and History of Life, Vautierstraat, 29, B-1000 Brussels, Belgium; \\ louis.taverne@gmail.com. \\ ${ }^{2}$ Royal Belgian Institute of Natural Sciences (RBINS), OD Earth and History of Life, Vautierstraat 29, B-1000 Brussels \& \\ KU Leuven, Belgium; etienne.steurbaut@naturalsciences.be. \\ ${ }^{*}$ corresponding author
}

\begin{abstract}
The osteology of Luxembourgichthys friedeni (Delsate, 1999) gen. nov. from the marine Toarcian (Grandcourt Formation, Lower Jurassic) of Belgium and the Grand Duchy of Luxembourg is studied in detail. This fossil teleost fish was initially assigned to Pholidophorus, a genus that recently received an emended diagnosis (Arratia, 2013). The cranial characters of $L$. friedeni considerably differ from those that now define Pholidophorus and the Pholidophoridae, excluding its attribution to both this genus and this family. In $L$. friedeni the posttemporal fossa is completely located on the lateral face of the braincase and not on the rear of the skull as usual. Such a position is unique among "Pholidophoriformes" and justifies the peculiar generic status of this taxon. L. friedeni possesses three specialized characters (a beryciform foramen piercing the anterior ceratohyal, arcocentra associated to the chordacentra and ovoid scales devoid of the peg-and-socket system) suggesting it occupies a position crownward of most "pholidophoriforms", closer to Jurassic and younger teleosts with cycloid scales.
\end{abstract}

KEYWORDS: Teleostei, "Pholidophoriformes", Luxembourgichthys ("Pholidophorus") friedeni gen. nov., osteology, relationships, Lower Jurassic, Belgium, Grand Duchy of Luxembourg.

\section{Introduction}

The lower Toarcian strata of southeast Belgium and the Grand Duchy of Luxembourg, known as the Grandcourt Marls or the Grandcourt Formation, yield a rich and diverse ichthyofauna, comprising the saurichthyid Acidorhynchus Stensiö, 1925, the amiiform Caturus Agassiz, 1834, the semionotid Lepidotes Agassiz, 1832, the dapediids Dapedium Leach, 1822 and Tetragonolepis Bronn, 1830, the pachycormids Sauropsis Agassiz, 1832, Pachycormus Agassiz, 1833, Saurostomus Agassiz, 1833, Euthynotus Wagner 1860 and Haasichthys Delsate, 1999, the pholidophorid Pholidophorus Agassiz, 1832 (represented by two species) and the primitive cycloid teleost Leptolepis Agassiz, 1832 (Delsate, 1999a, b).

Delsate (1999c) described the new species Pholidophorus friedeni on the basis of specimens found in different Toarcian localities of the Grand Duchy of Luxembourg. He stated that this taxon was also recorded in Germany and attributed this new species to the genus Pholidophorus, although without giving any reason for his choice. Moreover, he expressed some doubts about this generic attribution. Fragmentary samples of the same species, collected in the lower Toarcian strata of Athus (southeast Belgium), are housed in the collection of the Royal Belgian Institute of Natural Sciences (Brussels), but were not studied until now.

The aim of this paper is to study the osteology of "Pholidophorus" friedeni in a more detailed way than had been previously done, to discuss its generic attribution and to establish more precisely its relationships within the "Pholidophoriformes".

It is to be noted once again that "Pholidophoriformes" are a very heterogeneous assemblage of archaic fossil teleosts with ganoid scales. This 'waste-bin' contains many families and genera not always closely related but anatomically close to the "classical" primitive teleosts with cycloid scales, i.e. Leptolepis coryphaenoides (Bronn, 1830) and more advanced species (Patterson, 1973; Arratia, 2000, 2013; Taverne, 2011a). Taverne (2011c, 2014 a, b) has begun the break-up of this polyphyletic and artificial order into monophyletic units and has already created three orders, Ligulelliformes, Catervarioliformes and Ankylophoriformes, respectively for Ligulellidae, Catervariolidae and Ankylophoridae, three families formerly included within the "Pholidophoriformes". Arratia (2013) has also proposed to use henceforth the name Pholidophoriformes for the family Pholidophoridae only, an opinion that is shared here. That is why we use in our paper
"Pholidophoriformes" when referring to all the lineages ever included in this polyphyletic order and Pholidophoriformes when we only consider the Pholidophoridae.

\section{Stratigraphy of the Lower Jurassic in Belgium and the Grand Duchy of Luxembourg}

The Lower Jurassic deposits of Belgium and the Grand Duchy of Luxembourg (GD of Luxembourg in what follows) were deposited in what is often called the "Golfe du (Gulf of) Luxembourg". This bay-like extension of the Paris Basin, was located between the London-Brabant-Ardennes Landmass and the Rhenish Massif, connecting the Paris Basin with the epicontinental seas of the Netherlands and northern Germany (Fig. 1A; see also Monari et al., 2011). The deposits show a convex outcrop pattern, covering the extreme southeast of Belgium (Belgian Lorraine, including the Gaume in the west and the "Pays d'Arlon" (Country of Arlon) in the east) and the southern half of the GD of Luxembourg (essentially Guttland) (Fig. 1B). They extend into French Lorraine in the west and Germany (Saarland and Rheinland-Pfalz) in the east. The strata become progressively younger in a southward direction, more precisely south-southeastward in Belgium and south-southwestward in the GD of Luxembourg. The Lower Jurassic is represented in both areas by an up to $340 \mathrm{~m}$ thick heterogeneous succession of clay, marl and sandstones, with numerous limestone intercalations. This succession is subdivided into a series of formations, which received generally distinct names in both areas, although they are represented by almost the same facies (Fig. 2).

The Lower Jurassic of Belgium, subdivided into eight formations (Boulvain et al., 2001), starts with the Jamoigne Formation, which is Hettangian in age. It is an essentially marly unit, but contains several limestone and sandstone intercalations, and is around $40 \mathrm{~m}$ thick. Its thickness is increasing in southward direction to about $70 \mathrm{~m}$. It is overlain by the Luxembourg Formation, an alternation of sandstone, sand and gravel beds, and which is up to $100 \mathrm{~m}$ thick (Van den Bril \& Swennen, 2008). This unit, the base of which is diachronic, encompasses the top of the Hettangian and the entire Sinemurian. In eastward direction its upper part passes into marls, constituting the Arlon Formation, which reaches in the Arlon area up to $60 \mathrm{~m}$. It is subdivided into three members, of which the Strassen Member is the lowermost (Fig. 2). Both the Luxembourg and the Arlon Formations are covered by a 


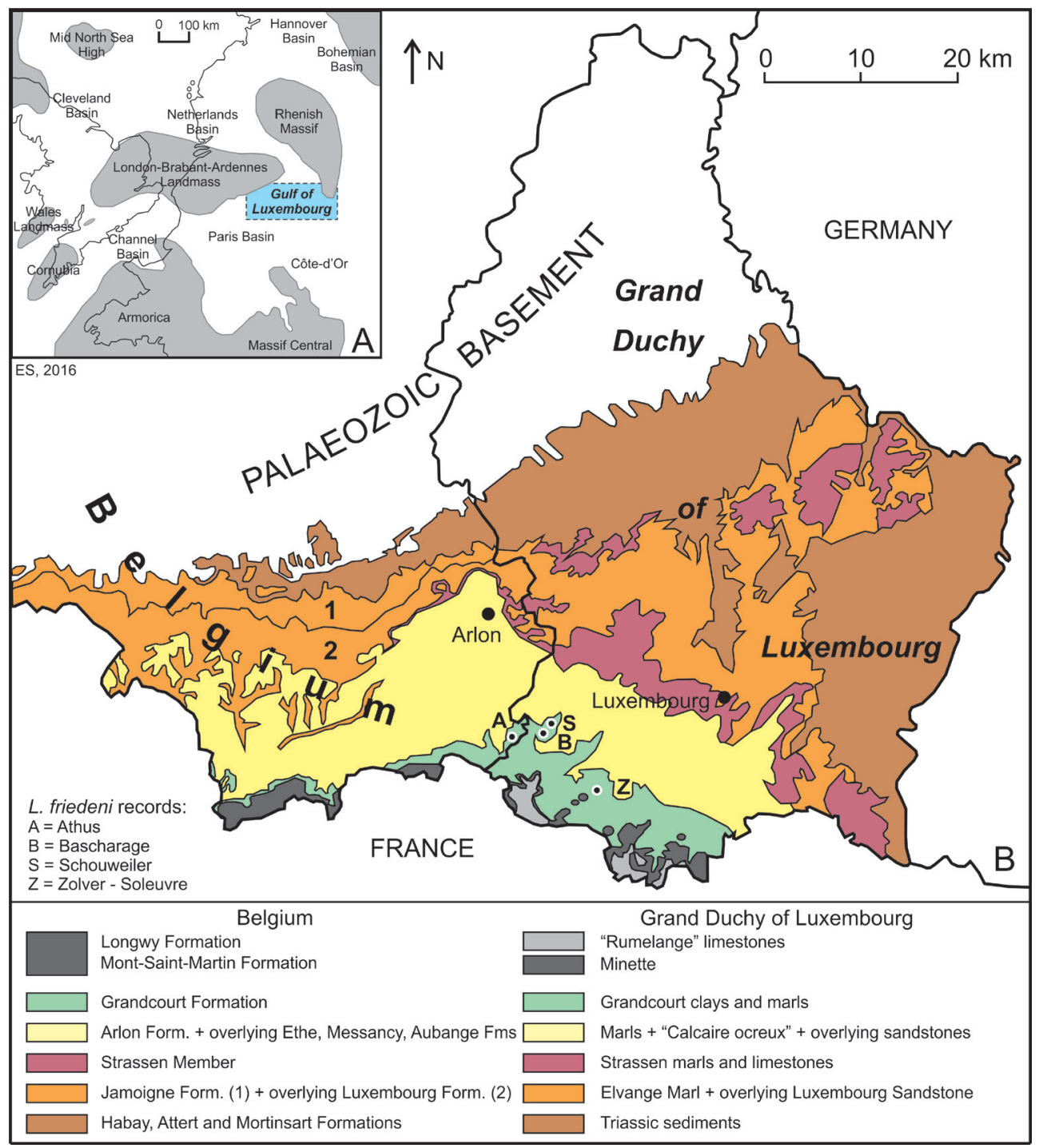

Figure 1. Geographical and geological context of the Luxembourgichthys friedeni (Delsate, 1999) records studied here. A. Paleogeographical map of NW Europe during Early Jurassic times (after Monari et al., 2011). B. Simplified geological map of SE Belgium and the southern part of the GD of Luxembourg (after Boulvain et al., 2001 and Schintgen \& Förster, 2013; modified)

series of essentially marly formations, in ascending order the Ethe Formation (laminar marls and clays up to $50 \mathrm{~m}$ thick), the Messancy Formation (sandy marls up to $35 \mathrm{~m}$ thick) and the Aubange Formation (sandy marl with limestone intercalations, generally around $40 \mathrm{~m}$ ), all three belonging to the Pliensbachian. The top of the Lower Jurassic (Toarcian) is represented by the Grandcourt Formation and the lower part of the overlying Mont-Saint-Martin Formation. The former is an up to $60 \mathrm{~m}$ thick bituminous clay and marl, with a thin silty-calcareous lamination (also known as "Schistes Cartons" (paper shales)), passing towards the top into a sandier laminated marl rich in septaria. The Mont-Saint-Martin Formation is an argillaceous sandstone and ferruginous marl with iron oolite beds, representing a $40 \mathrm{~m}$ thick succession of which the top already belongs to the Middle Jurassic (Aalenian). It is overlain by the Longwy Formation, an up to $50 \mathrm{~m}$ thick limestone succession of Bajocian age, including locally some conglomeratic layers.

Almost identical facies are recorded in the Lower Jurassic from the GD of Luxembourg (Fig. 2, after Schintgen \& Förster, 2013, which produced detailed isopach maps for the different units or groups of units). The Hettangian to Sinemurian succession consists of three lithostratigraphic units, in ascending order, the Elvange Marl, up to $40 \mathrm{~m}$ thick, roughly corresponding to the Jamoigne Formation in southern
Figure 2. Lithostratigraphic classification of the Lower and Middle Jurassic of SE Belgium and the GD of Luxembourg (after Boulvain et al., 2001, Belanger et al., 2002 and Schintgen \& Förster, 2013; modified).

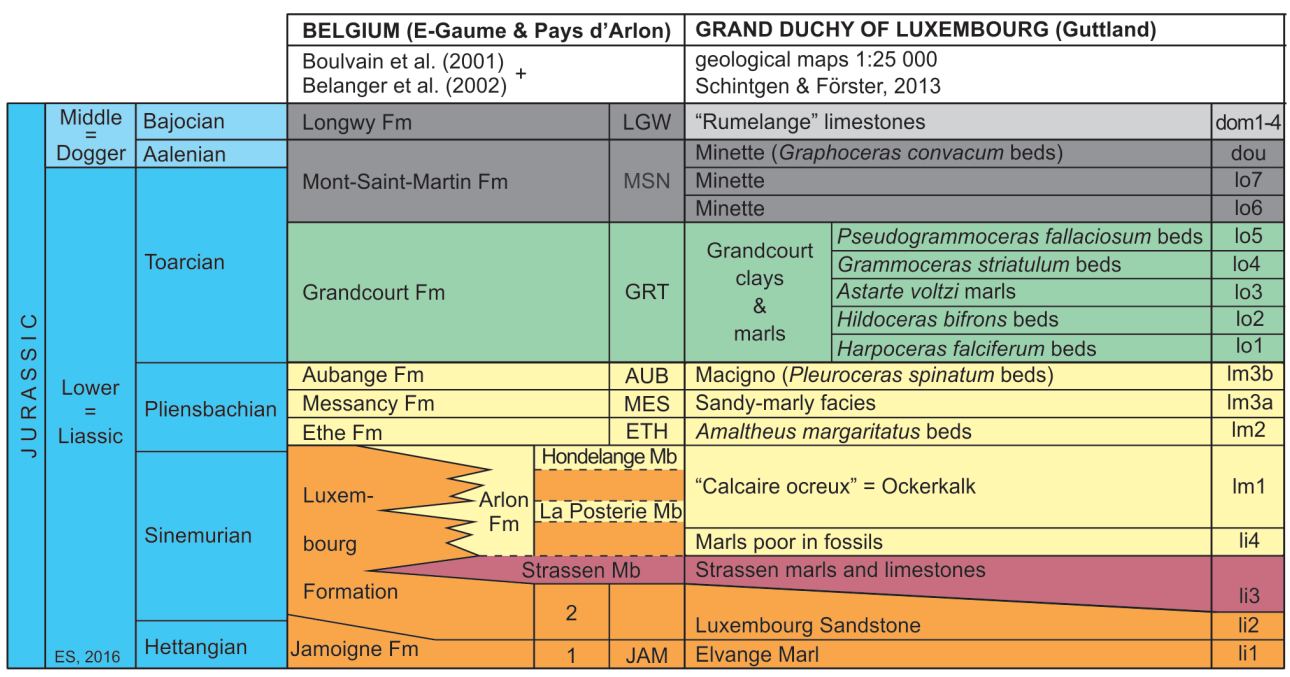




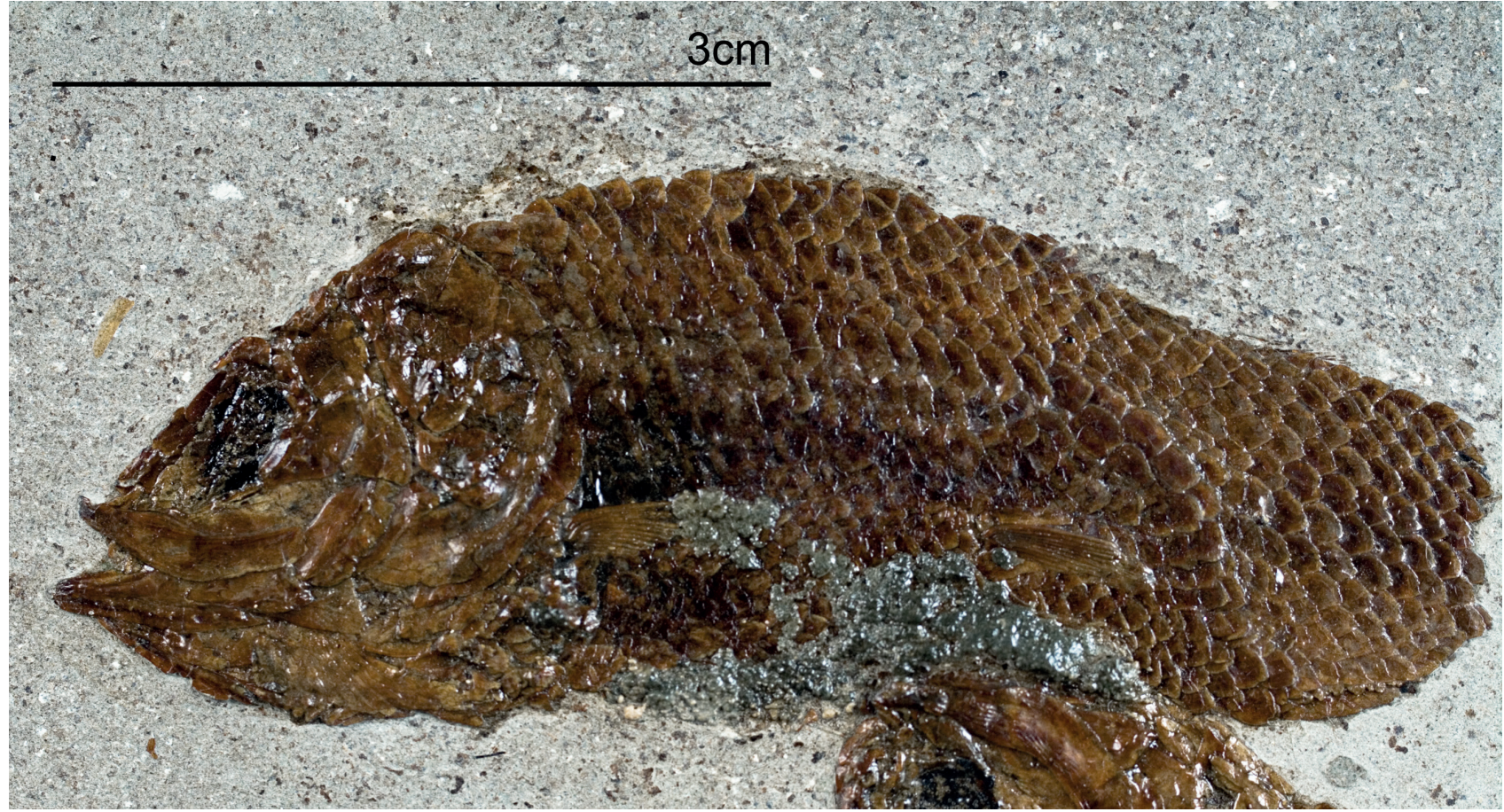

Figure 3. Luxembourgichthys friedeni (Delsate, 1999). Holotype MNHNL Nº TU 988 A (former MF 17 A).

Belgium, the Luxembourg Sandstone Formation, up to $100 \mathrm{~m}$ thick and the Strassen marl and limestone unit, about $40 \mathrm{~m}$ thick (Monari et al., 2011; Schintgen \& Förster, 2013). The latter is an informal lateral equivalent of the lower Arlon Formation, which in Belgium has received separate status and has officially been named Strassen Member. It is overlain by an unnamed up to $50 \mathrm{~m}$ thick marl unit and by the "Calcaire ocreux" (Ockerkalk) ( 20 m), a greenish-grey and reddishbrown limestone unit, with locally marls and iron oolites, which corresponds to the upper Arlon Formation in Belgium. The essentially marly Pliensbachian of Belgium (Ethe and Messancy Formations) passes in eastward direction into the "Amaltheus margaritatus beds" (over $100 \mathrm{~m}$ thick) and the overlying informal "sandy-marly facies unit" also known as the "Grès médioliasique" (middle Liassic sandstone) (Schintgen, 2015, fig. 2). The latter is covered by the sandy (macigno) "Pleuroceras spinatum beds", which are a correlative of the Belgian Aubange Formation. These beds are in turn covered by the "Argiles et marnes de Grandcourt" (Grandcourt clays and marls) (Schintgen, 2015), an up to $160 \mathrm{~m}$ thick series of marls, which are informally subdivided in five units and which yielded most of the fish material studied here (see Fig. 2). The top of the Lower Jurassic is represented by the lower part of the Minette ironstone Formation. Its uppermost part and the overlying "Rumelange" limestones (subdivided into five units) belong to the Middle Jurassic, to the Aalenian and Bajocian respectively.

\section{Material and methods}

Material studied belongs to the collections of the National Museum of Natural History of Luxembourg (MNHNL) and the Royal Belgian Institute of Natural Sciences (IRSNBKBIN). It has been collected in the outcrop belt of the Grandcourt Formation, essentially in the SW of the Grand Duchy of Luxembourg (in the localities of Schouweiler, Bascharage and Zolver-Soleuvre occurring in a $5 \mathrm{~km}$ wide zone $\mathrm{N}$ and S of Sanem, $16 \mathrm{~km} \mathrm{SW}$ of Luxembourg) and to a lesser degree in the nearby locality of Athus, in the extreme SE point of Belgium (Fig. 1B). The samples were observed with a stereomicroscope Wild M5. The drawings of the figures were made by the first author (L.T.) with a camera lucida. Aspersions with ethanol were used to improve the observations.

\section{Anatomical abbreviations used in the text figures}

AN: angular; ANT: antorbital; APAL: autopalatine; APTE: autopterotic; ART: articular; ASPH: autosphenotic; BO: basioccipital; BRSTG: branchiostegal rays; $\mathrm{BSPH}$ basisphenoid; CHY a.: anterior ceratohyal; CLA: clavicle; CLT: cleithrum; COR: hypocoracoid; DETH: dermethmoid (= rostral); DN: dentary; DPTE: dermopterotic; DSPH: dermosphenotic; ECPT: ectopterygoid; ENPT: entopterygoid (= endopterygoid); EPI: epiotic (= epioccipital); FR: frontal; FU (b., fr.): fulcrum (basal, fringing); GU: gular plate; HCLT: hypercleithrum (= supracleithrum); IC: intercalary; IOP: interopercle; IORB 1-5: infraorbitals 1 to 5; LDETH: lateral dermethmoid; LEP: lepidotrichia (= fin rays); LETH: lateral ethmoid; MPT: metapterygoid; MX: maxilla; NA: nasal; OP: opercle; OSPH: orbitosphenoid; PA: parietal; PCLT: postcleithrum; PMX: premaxilla; POP: preopercle; PORB: postorbital (= suborbital); PS: parasphenoid; PSPH: pleurosphenoid (= pterosphenoid); PT: posttemporal; QU: quadrate; RAD: pterygiophores; RART: retroarticular; SAN: surangular; SC: scale; SCA + COR: fused hypercoracoid (= scapula) and hypocoracoid (= coracoid); SCL: sclerotic bone; SCU: caudal scute; SMX 1, 2: supramaxillae 1 and 2; SOC: supraoccipital; SOP: subopercle; SORB 1-3: supraorbitals 1, 2 and 3; ST: supratemporal (= extrascapular, scalebone); SY: symplectic; ext. c.: extrascapular sensory commissure; iorb. c.: infraorbital sensory canal; 1.: left; 1.1.c: lateral line sensory canal; m. c.: mandibular sensory canal; op. f.: optical fenestra; pop. c.: preopercular sensory canal; sorb. c.: supraorbital sensory; pt. f.: posttemporal (= temporal) fossa; q. pr.: bony quadratic process of the quadrate; r.: right; r. c.: rostral sensory commissure; sorb. f.: supraorbital fossa.

\section{Systematic paleontology}

Division Teleostei Müller, 1845

Order "Pholidophoriformes" Berg, 1940 (not sensu Arratia, 2013)

Family incertae sedis

\section{Genus Luxembourgichthys gen. nov.}

Type species. Pholidophorus friedeni Delsate, 1999 (here designated). 


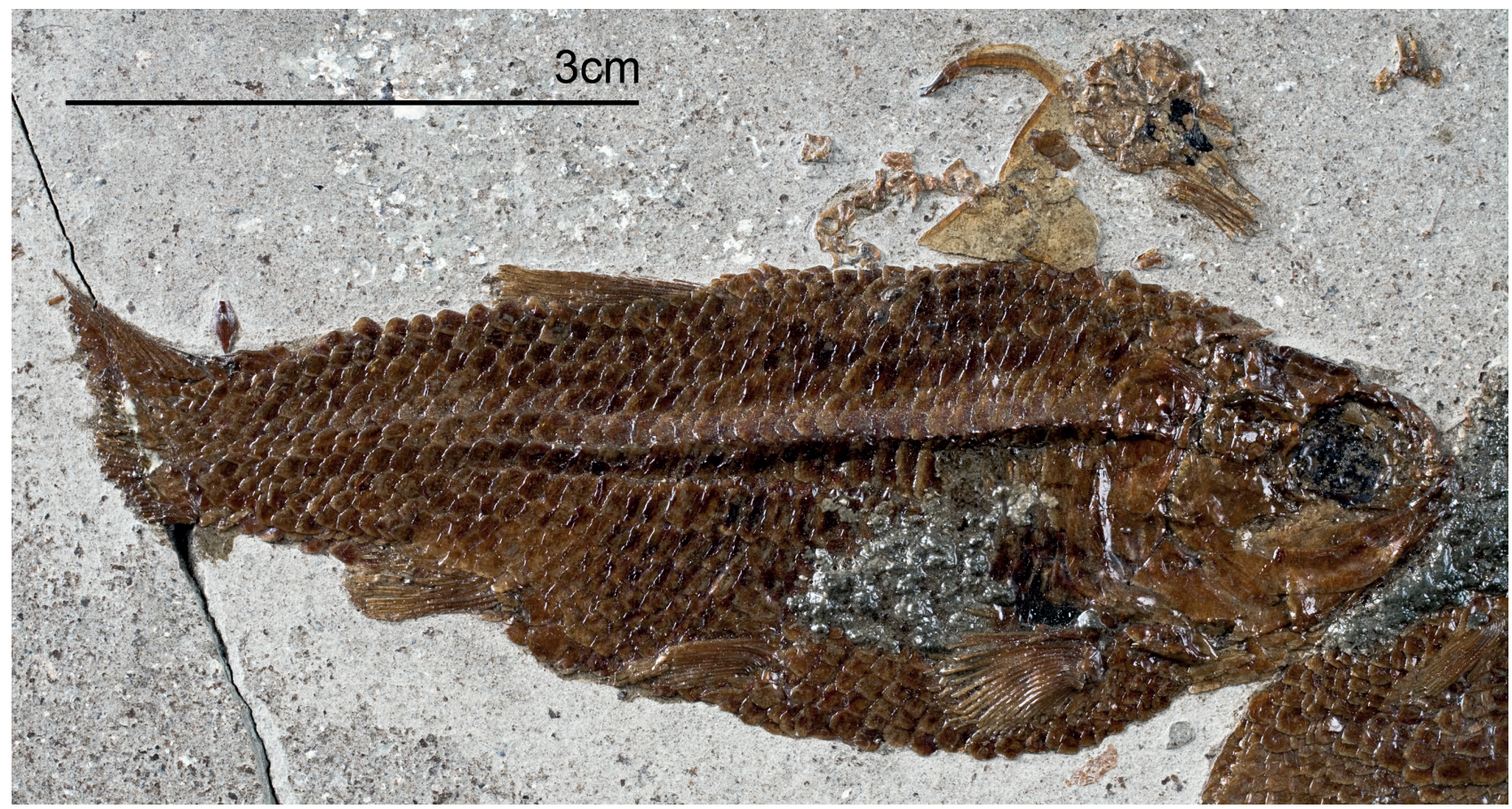

Figure 4. Luxembourgichthys friedeni (Delsate, 1999). Paratype MNHNL Nº TU 988 B (former MF 17B).

Diagnosis. As for the species (monospecific genus).

Etymology. The generic name refers to the Grand Duchy of Luxembourg and to the Belgian province Luxembourg. The Greek word ichthys, fish, is added.

\section{Luxembourgichthys friedeni (Delsate, 1999)}

\section{Synonymy.}

Pholidophorus nov. sp. - Delsate, 1999a, p. 54, fig. 20.

? Pholidophorus friedeni nov. sp. - Delsate, 1999c, p. 143, figs 1-13.

Emended diagnosis. Small teleost with ganoid scales. Bones of the skull roof sutured together. Endocranium ossified, with individualized bones. Ossified supraoccipital present. Small dermethmoid bearing the rostral sensory commissure. Nasals meeting in the mid-line and separating the dermethmoid from the frontals. Nasal devoid of foramen for the nostril. Paired toothless lateral dermethmoid present. Large lateral ethmoid. Frontal with a broad anterior extremity. Interorbital fenestra present. Large orbitosphenoid with wide supraorbital fossae and anteriorly reaching the lateral ethmoid. Parasphenoid toothless. Wide posttemporal fossa laterally located and surrounded by the parietal, the dermopterotic, the autopterotic, the intercalary and the epiotic. Large supratemporal covering the posttemporal fossa. Well-developed bony process on the quadrate. One large postorbital (= suborbital). Preopercle crescent-shaped, with a broad ventral region and a narrow dorsal limb. Numerous secondary tubules on the preopercular sensory canal. Upper jaw toothless. Lower jaw toothless or feebly toothed. Leptolepid notch on the dentary weakly marked. Gular plate present. Anterior ceratohyal with a small beryciform foramen. Clavicle present. Vertebrae with chordacentra and autocentra. Dorsal fin origin behind the pelvic girdle level. Pectoral fin without fringing fulcra. Dorsal, ventral, anal and caudal fins with fringing fulcra. Caudal fin containing 24 principal rays. Scales of irregular shape, most of them devoid of the peg-and-socket system.

Holotype. MNHNL Nº TU 988 A (former MF 17 A), a specimen preserved in left lateral view and measuring $60 \mathrm{~mm}$ long, from Schouweiler, GD of Luxembourg (Fig. 3). The skull roof, the most caudal part of the body and the tail are missing.

Figure 5. Luxembourgichthys friedeni

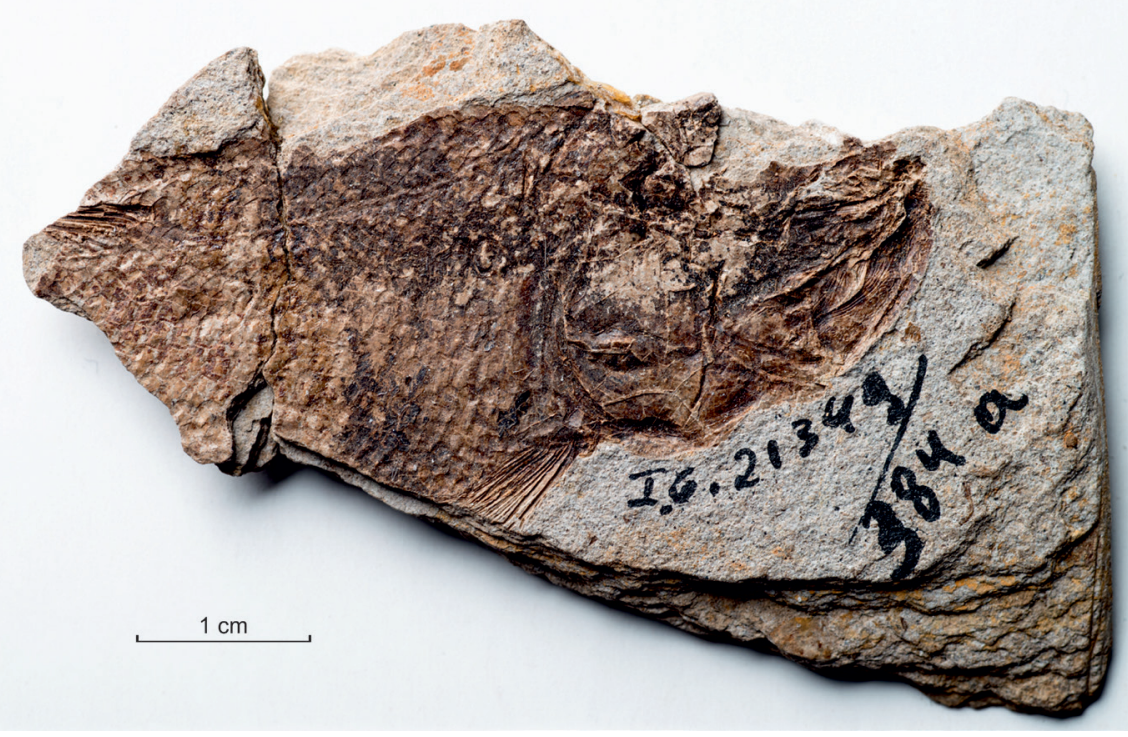

(former IG 21.349, $\mathrm{N}^{\circ} 384 \mathrm{~A}$ ) 


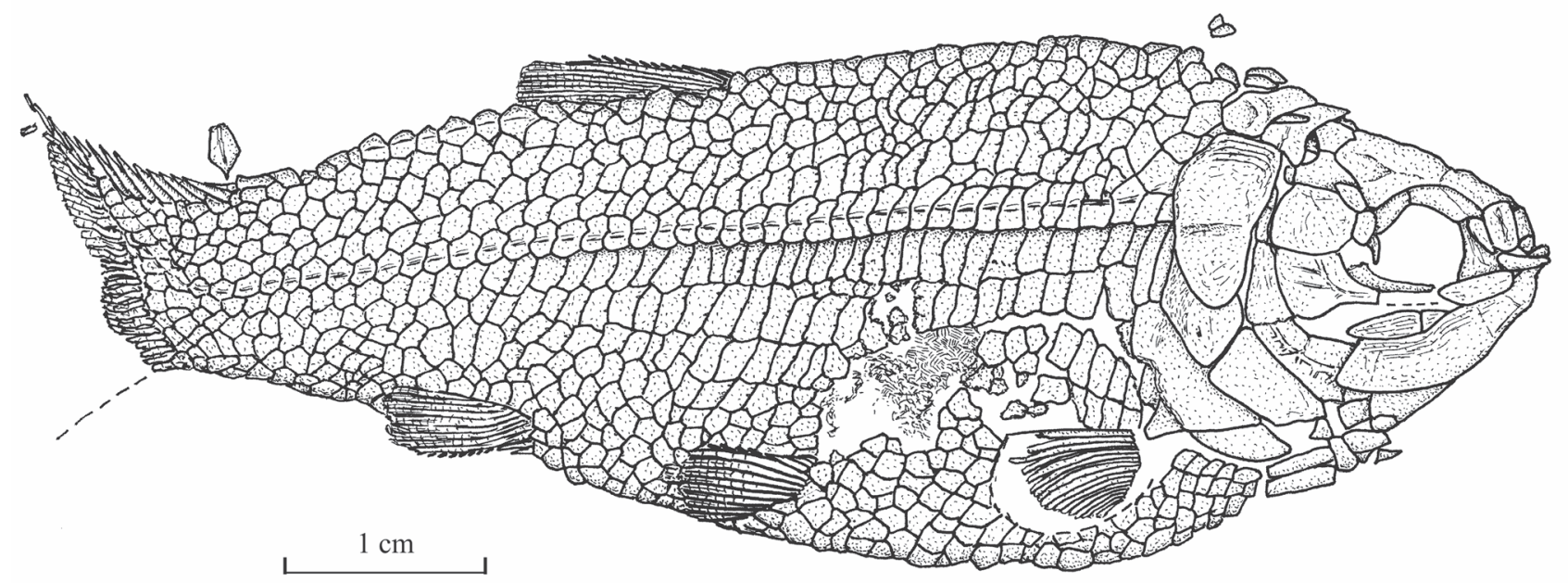

Figure 6. Luxembourgichthys friedeni (Delsate, 1999). Reconstruction of paratype MNHNL Nº TU 988 B (former MF 17B).

Paratype. MNHNL $\mathrm{N}^{\circ}$ TU 988 B (former MF 17B), a nearly complete specimen preserved in right-lateral view and $73 \mathrm{~mm}$ long (Fig. 4). A part of the caudal fin is missing. The paratype rests on the same plate as the holotype.

Other material. MNHNL $\mathrm{N}^{\circ}$ TU 763 A, B, part and counterpart of a badly preserved and incomplete specimen, 51 $\mathrm{mm}$ long, from Bascharage, GD of Luxembourg. The caudal part of the body and the tail are missing.

IRSNB P 9693 (former IG 22.669, N 5 A, B), part and counterpart of a badly preserved and incomplete specimen, $60 \mathrm{~mm}$ long, from Athus, Belgium. IRSNB P 9694 (former IG 21.349, $\left.\mathrm{N}^{\circ} 906 \mathrm{~A}, \mathrm{~B}\right)$, part and counterpart of a badly preserved skull and beginning of body, from Athus, Belgium. IRSNB P 9695 (former IG 21.349, N 384 A, B), part and counterpart of a partly preserved skull and beginning of the body, from Athus, Belgium (Fig. 5). IRSNB P 9696 (former IG 21.349, $\left.\mathrm{N}^{\circ} 67-01\right)$, the sphenoid region of a braincase in ventral view, from Athus, Belgium. IRSNB P 9697 (former IG 22.097, $\mathrm{N}^{\circ} 105-05$ ), part and counterpart of a lower jaw, from Athus Belgium.

Morphometric data (Fig. 6). The paratype is the only known specimen showing the head and the complete body. Its dorsal, anal and ventral fins are preserved. That is not the case with the holotype. The paratype is thus chosen to exemplify the external morphology of the species. The morphometric characters are given in percentage of the standard length (66 $\mathrm{mm}$ ): head length (with the opercle) $28.0 \%$, head depth (in the occipital region) $23.6 \%$, maximum body depth (just behind the head) $39.8 \%$, body depth before the ventral fins $36.7 \%$, body depth before the anal fin $23.3 \%$, caudal peduncle depth $15.2 \%$, predorsal length $59.1 \%$, preanal length $75.9 \%$ and prepelvic length $52.6 \%$.

\section{Osteology}

1. - The skull (Figs 7-17)

The dermal bones of the skull are covered by a thin layer of ganoine but are not ornamented except on the jaws. The endochondral bones of the braincase are clearly separated by sutures. Small fragments of the dermethmoid (= rostral) are preserved on the paratype, just before the nasal, and also on specimen TU 763, just behind the premaxillae. A complete dermethmoid, with the rostral sensory commissure, is visible on specimen IRSNB P 9695 A. The dermethmoid is a rather small and more or less rounded bone. The right toothless lateral dermethmoid is visible on the paratype. It is a long but rather narrow bony tongue-like strip that anteriorly reaches the level of the premaxilla and maxilla. A large fragment of the same bone is preserved on specimen IRSNB P 9695 A.

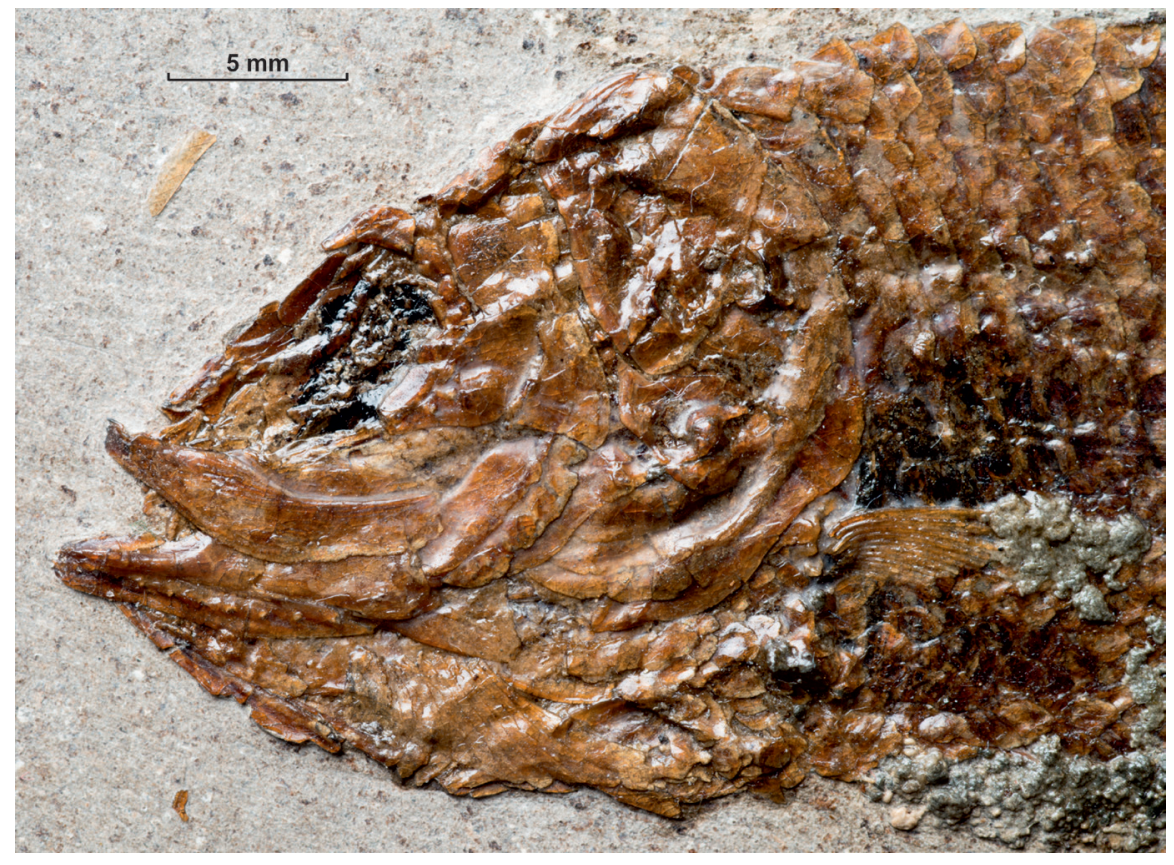

Figure 7. Luxembourgichthys friedeni (Delsate, 1999). Head region of holotype MNHNL N TU 988 A (former MF 17 A). 


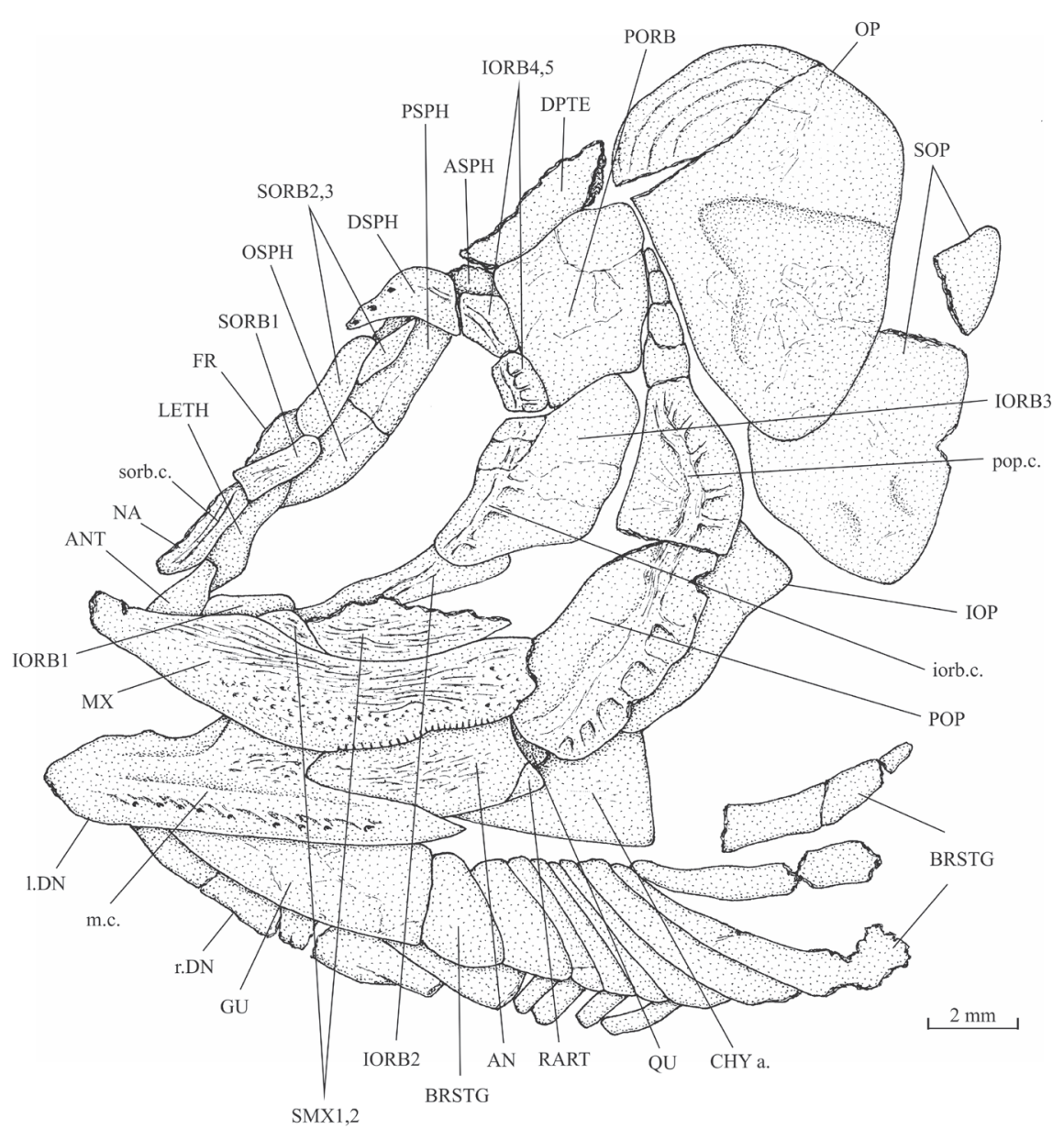

Figure 8. Luxembourgichthys friedeni (Delsate, 1999). Skull of holotype MNHNL $\mathrm{N}^{\circ} \mathrm{TU} 988 \mathrm{~A}$ (former MF $17 \mathrm{~A}$ ).

The holotype has lost a part of the left nasal but the complete right nasal is preserved on the paratype. The two nasals are visible in dorsal view on specimen IRSNB P 9694 A. The nasal is a large broad bone bearing the anterior portion of the supraorbital sensory canal. Their anterior regions meet on the mid-line. The dermethmoid is thus largely separated from the frontals. Posteriorly, the two nasals are separated from each other by the frontals. The nasal does not bear a foramen for the nostril. The lateral ethmoids are well developed and more or less triangular in shape when seen in lateral view, with their thin tip contacting the frontal and their enlarge bases resting on the parasphenoid. The vomer, the hypoethmoid and the supraethmoid are unknown, the two last elements remaining perhaps cartilaginous.
The skull roof is much broader in the postorbital region than at the orbital level. The bones of the skull roof are sutured together. There is no tendency of fusion between these elements. There is no frontal fontanel. The frontals are long, broader in the postorbital region than anteriorly. The anterior extremity of the frontal is pointed but rather broad. The parietals are large bones, much broader than long. They meet at the mid-line (medioparietal skull). The autosphenotics are small bony nodules appended to the frontals. The dermopterotics are rather short, with a small dorsal process meeting the parietal. The posterior region of the right intercalar is visible on the paratype, articulated on the rear of the pterotic. A part of the supraoccipital is also visible on the paratype, the bone having rent the overlying supratemporal. A

Figure 9. Luxembourgichthys friedeni (Delsate, 1999). Head region of paratype MNHNL $\mathrm{N}^{\circ}$ TU 988 B (former MF 17B).

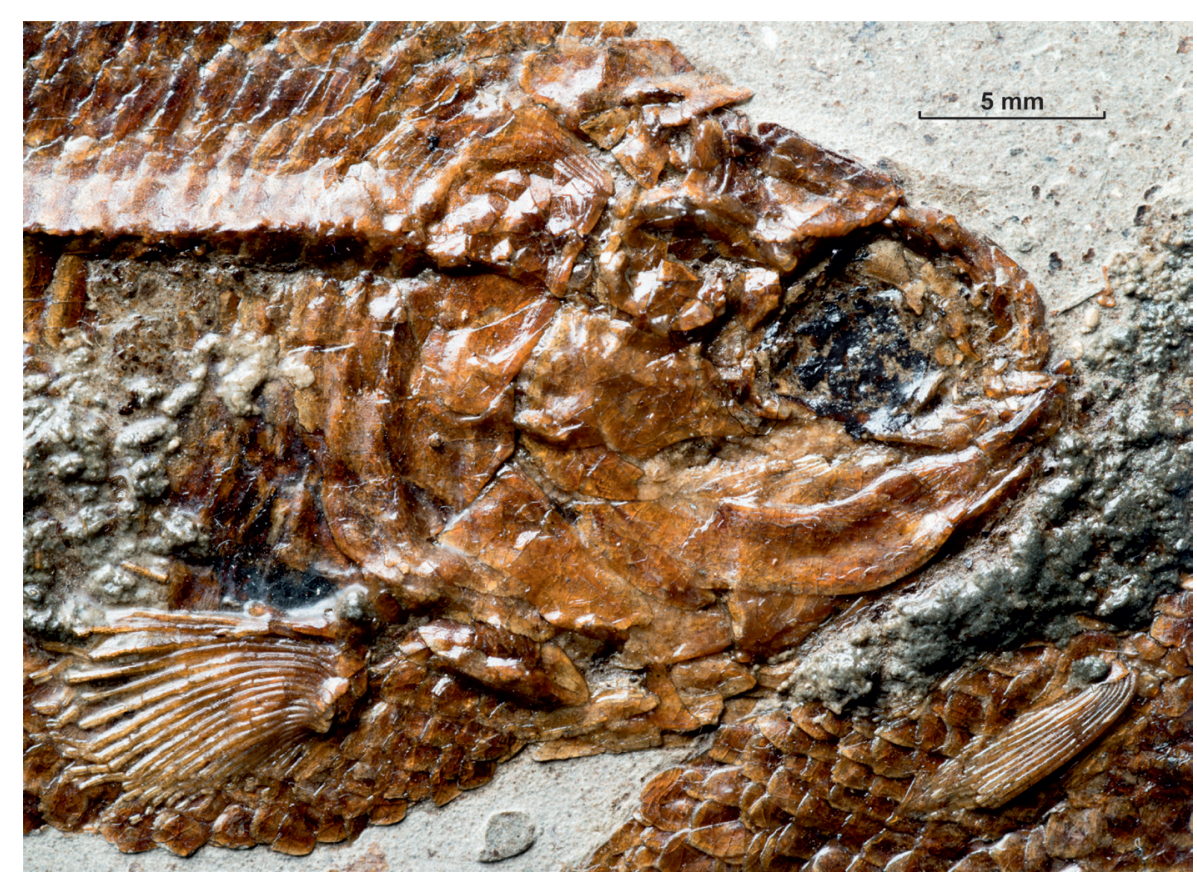




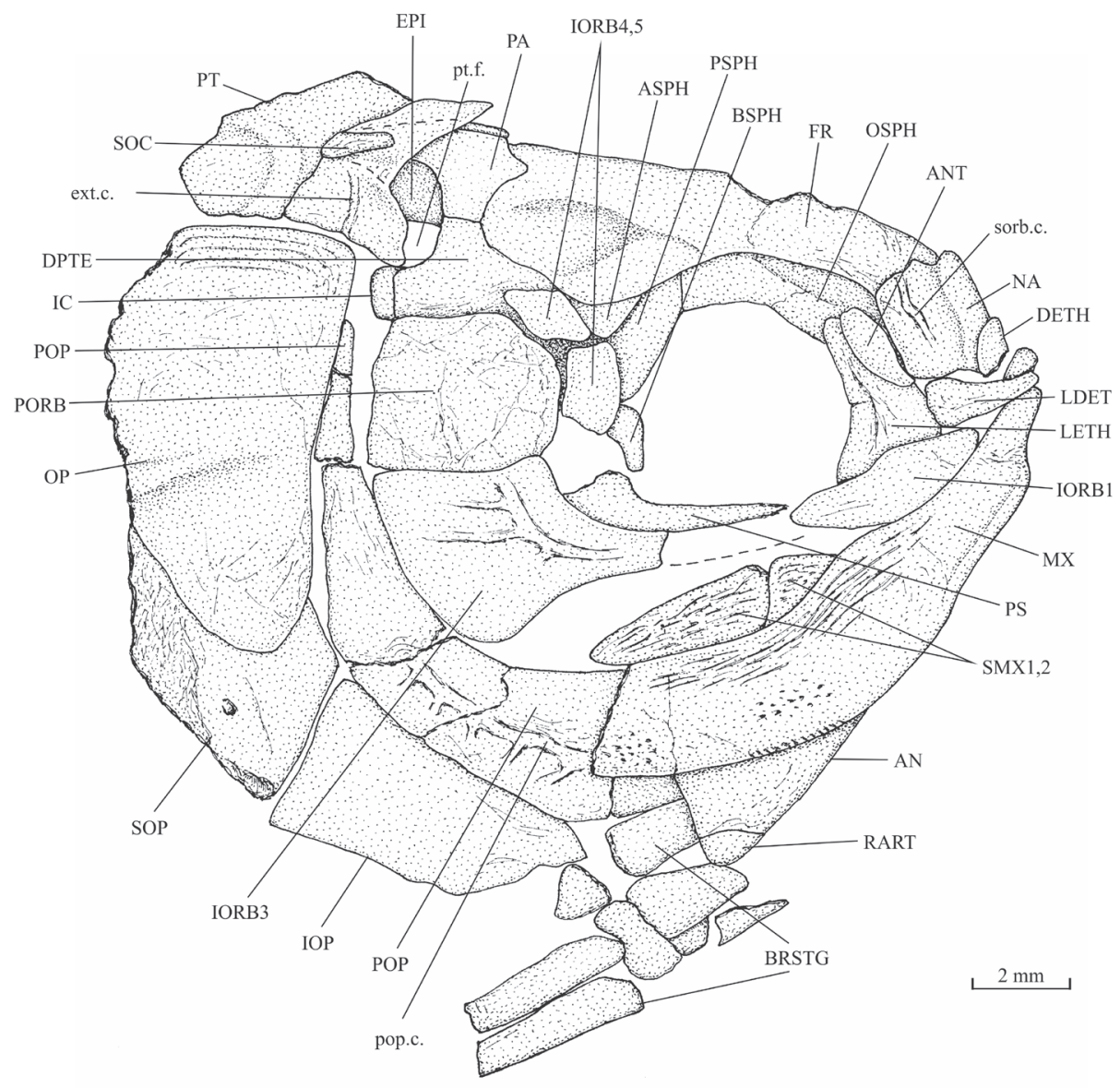

Figure 10. Luxembourgichthys friedeni (Delsate, 1999). Skull of paratype MNHNL $\mathrm{N}^{\circ} \mathrm{TU} 988 \mathrm{~B}$ (former MF 17B).

part of the right epiotic (= epioccipital) is visible on specimen IRSNB P 9694 B.

The posttemporal (temporal) fossa does not open on the rear of the skull but is laterally located. The fossa is roofed by the parietal which also forms its dorsal border and the upper part of its lateral border, while the dermopterotic composes the lower part of this border and the autopterotic its floor. The intercalar reaches the ventral border of the fossa. The medial wall of the fossa is formed by the epiotic. The fossa is partly covered by a large triangular supratemporal (= extrascapular) that meets the mid-line of the skull.

The orbitosphenoid and the pleurosphenoids are separated from the parasphenoid by a broad interorbital fenestra. The orbitosphenoid is a very large bone, much larger than the pleurosphenoids. Anteriorly, the orbitosphenoid is sutured with the lateral ethmoids. Such a sphenoid morphology is very different from that of Leptolepis, the other teleost present in the Toarcian deposits of Athus, where the orbitosphenoid
Figure 11. Luxembourgichthys friedeni (Delsate, 1999). Skull roof of specimen IRSNB P 9694 (former IG 21.349, № 906 A [left] and $N^{\circ} 906 \mathrm{~B}$ [right]).

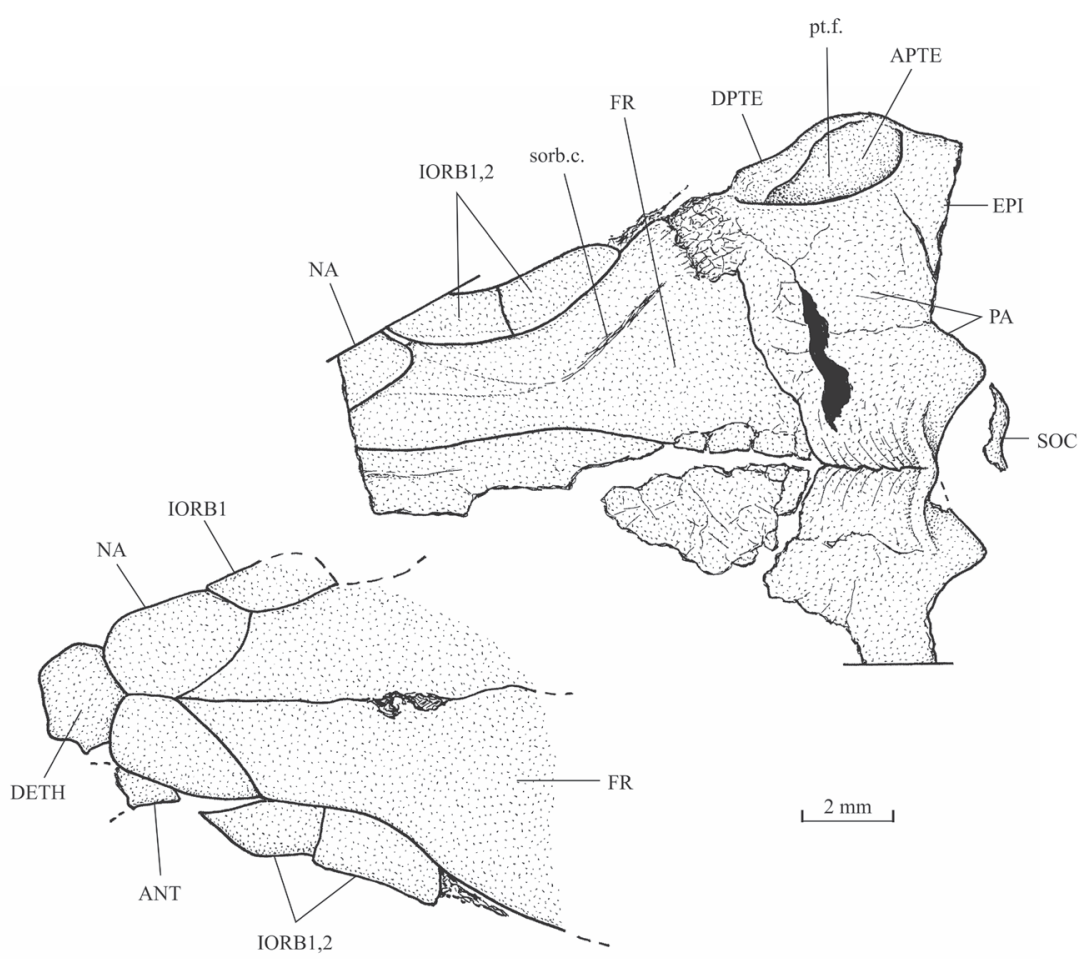




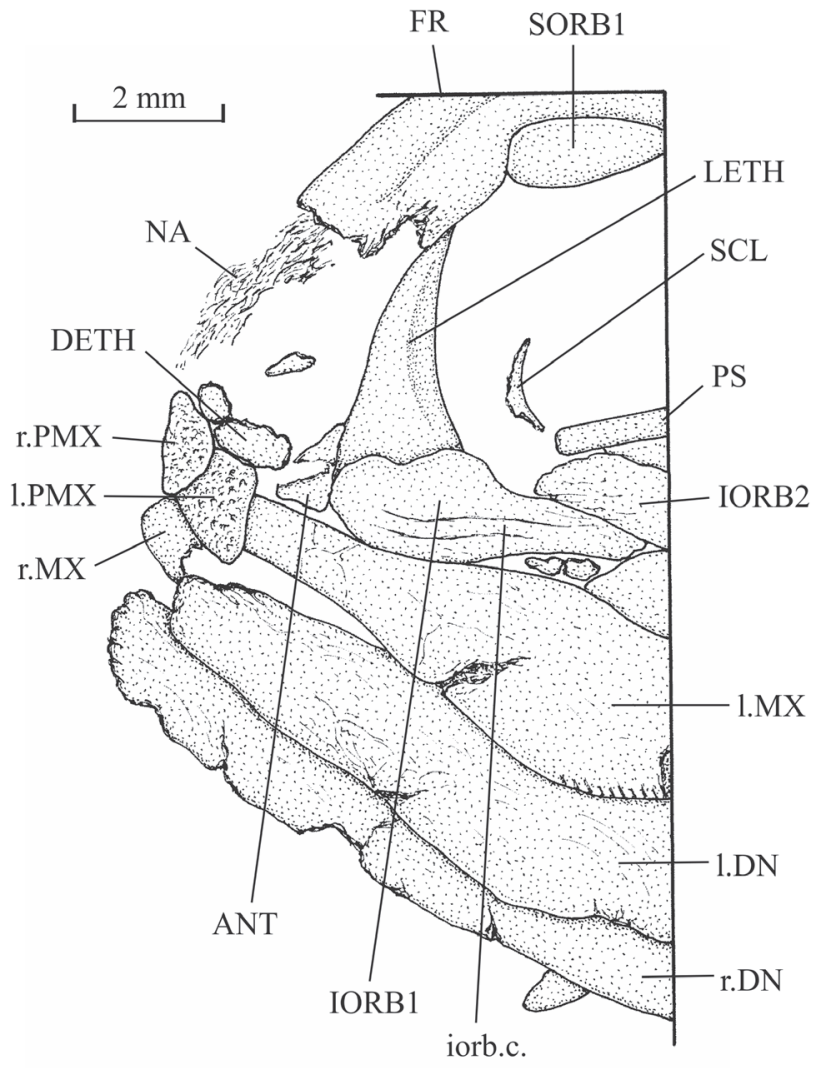

Figure 12. Luxembourgichthys friedeni (Delsate, 1999). Snout region of specimen MNHNL $\mathrm{N}^{\circ} \mathrm{TU} 763$.

is largely separated from the lateral ethmoids and is much smaller than the pleurosphenoids. A pair of wide supraorbital fossae is well marked on the orbitosphenoid of specimen IRSNB P 9696. The well-developed basisphenoid is visible on the paratype and on IRSNB P 9696. There is a broad fenestra between the orbitosphenoid, the pleurosphenoids and the basisphenoid for the emergence of the two optic nerves (II). The trabecular part of the parasphenoid is a thin toothless rod-like bone.
The palatine arch is well preserved in specimen IRSNB P 9695 A, B. The palatine is well developed, with an anterior dorsal process that was probably articulated with the lateral ethmoid and with the maxilla. The entopterygoid, the metapterygoid and the quadrate are large bones. The entopterygoid seems toothless. Only a small part of the ectopterygoid is visible between the supramaxillae, the maxilla and the palatine. The quadrate is triangular and it bears a well-developed bony quadrate process that is parallel to the lower margin of the bone.

The upper jaw is toothless. The premaxillae meet at the symphysis and cover the laterodermethmoids. The premaxillae are small, more or less triangular in shape, deeper anteriorly than posteriorly and their surface is ornamented with coarse granulations. The maxilla is a large curved bone, as long as the lower jaw. It is narrow anteriorly, at the level of the premaxilla, but broadens posteriorly, with its greatest depth just before the first supramaxilla where its dorsal border exhibits a small protuberance. The surface is ornamented with long and thin ridges on its upper part and by small granulations on its lower part. On the posterior half of its oral border, the maxilla bears no real teeth but a series of small indentations. There are two supramaxillae that lie in a depression on the upper margin of the maxilla. The anterior supramaxilla is very small. The posterior supramaxilla bears a short pointed anterior process passing over the first one, as seen on IRSNB P 9695A. Both supramaxillae also bear thin ridges on their surface.

The lower jaw is toothless on the holotype but bears four very small conical teeth on specimen IRSNB P 9697. The jaw articulates with the quadrate at the level of the posterior margin of the orbit. The dentary is rather narrow in its anterior half, with a more or less pointed symphysis, but it deepens abruptly in its posterior half to form a broad coronoid process with the wide angular and the small surangular. The deepened region of the dentary is externally reinforced by a thick vertical bony pillar as in Leptolepididae (Fig. 17, right; Rayner, 1937, fig. 4A) but the jaw is proportionally less deep than in Leptolepis. The leptolepid notch is completely open and so weakly marked. The external face of the dentary is devoid of the marked lateral ridge that separates the dental and splenial regions of this bone in Pholidophoridae (sensu Arratia, 2013), but the mandibular sensory canal forms a bony bulge all along the two faces of the dentary. Some thin ridges are present on the surface of the dentary and the angular. The mandibular canal lies near the lower border of the dentary

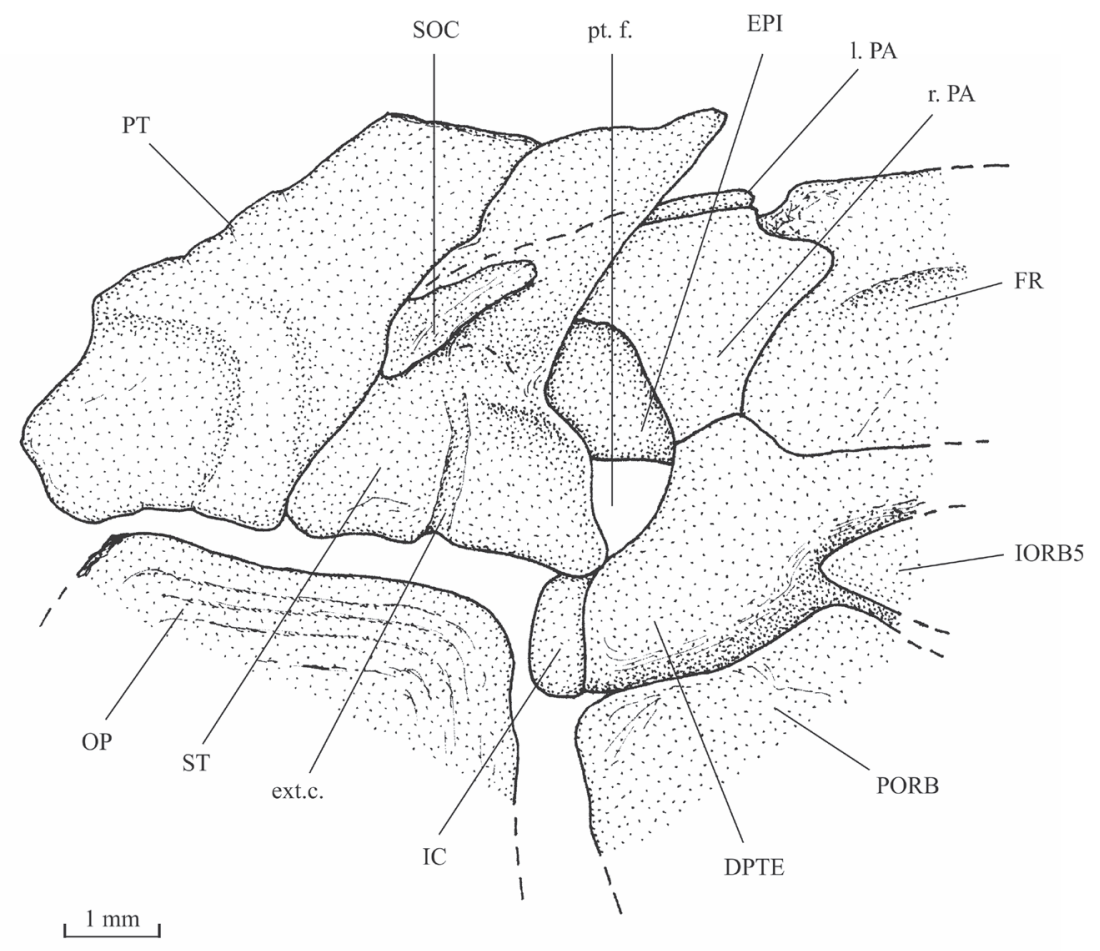

Figure 13. Luxembourgichthys frieden (Delsate, 1999). Temporal region of paratype MNHNL $\mathrm{N}^{\circ}$ TU $988 \mathrm{~B}$ (former MF 17B). 


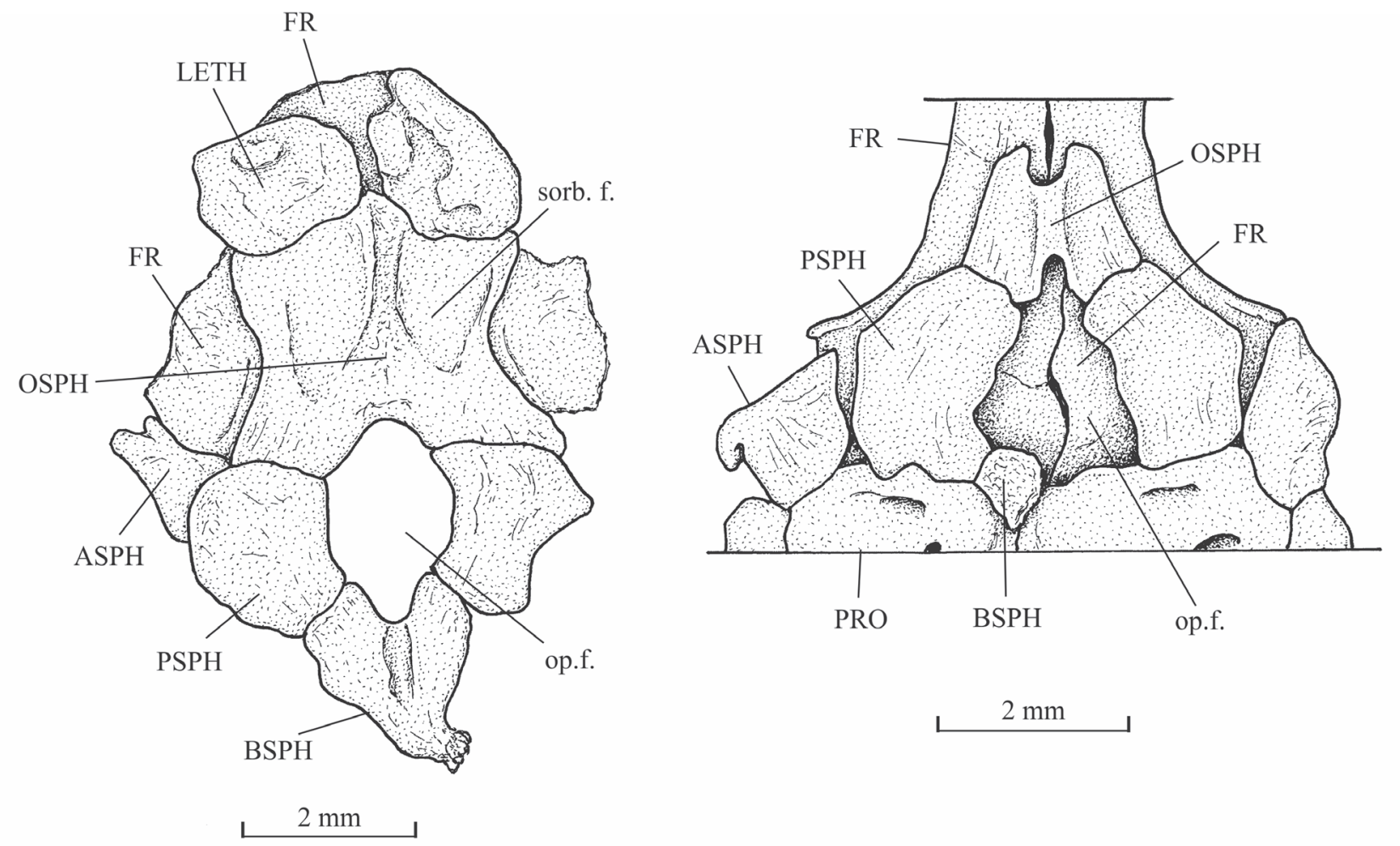

Figure 14. Sphenoid region of Luxembourgichthys friedeni (Delsate, 1999) (specimen IRSNB P 9696 [former I. G. 21.349, Nº 67-01]) [left] and of Leptolepis normandica Nybelin, 1962 (specimen on plate MNHNL N TU 988 A, B, with holotype and paratype of L. friedeni).

and opens ventrally by a series of very short branches. There is a small autogenous retroarticular. The internal face of the mandible is preserved in sample IRSNB P 9697. A large autogenous articular is visible. The bone is fused neither to the angular nor to the retroarticular.

The antorbital is small and triangular in shape. There are five infraorbitals. The first one is a long ovoid bone. The second infraorbital is still longer but also narrower. The third infraorbital is greatly enlarged and a little longer than deep. On the contrary, the fourth and fifth infraorbitals are small bones. The dermosphenotic also is small and more or less triangular in shape. There is only one large postorbital (= suborbital) resting on the dorsal border of the third infraorbital. Two supraorbitals lie along the frontal border. Anteriorly, the first supraorbital is in contact with the nasal. On the holotype, there is a small third supraorbital posterior to the two normal supraorbitals and lying under the dermosphenotic as in
Parapholidophorus nybelini Zambelli, 1975 from the Upper Triassic of northern Italy (Zambelli, 1975, figs 1, 2). The infraorbital sensory canal travels through the antorbital, the five infraorbital and the dermosphenotic. The canal produces a few short secondary tubules on the third and the fourth infraorbitals.

The preopercle is a crescent-shaped bone, with a broad ventral region and a long and very narrow upper limb that reaches the level of the lateral margin of the dermopterotic. The preopercular sensory canal runs through the preopercle a little nearer to its posterior margin and gives rise to five to nine short secondary tubules (see also Delsate, 1999c, fig. 5). The opercle is well developed and more or less triangular with a slightly rounded dorsal border. Some growth striae are visible near the dorsal margin of the bone. The subopercle also is a large bone but not as deep as the opercle. Its anterior upper corner forms a dorsal triangular process. The interopercle is
Figure 15. Luxembourgichthys friedeni (Delsate, 1999). Head region of specimen IRSNB P 9695 (former IG 21.349, $\mathrm{N}^{\circ} 384 \mathrm{~A}$ ).

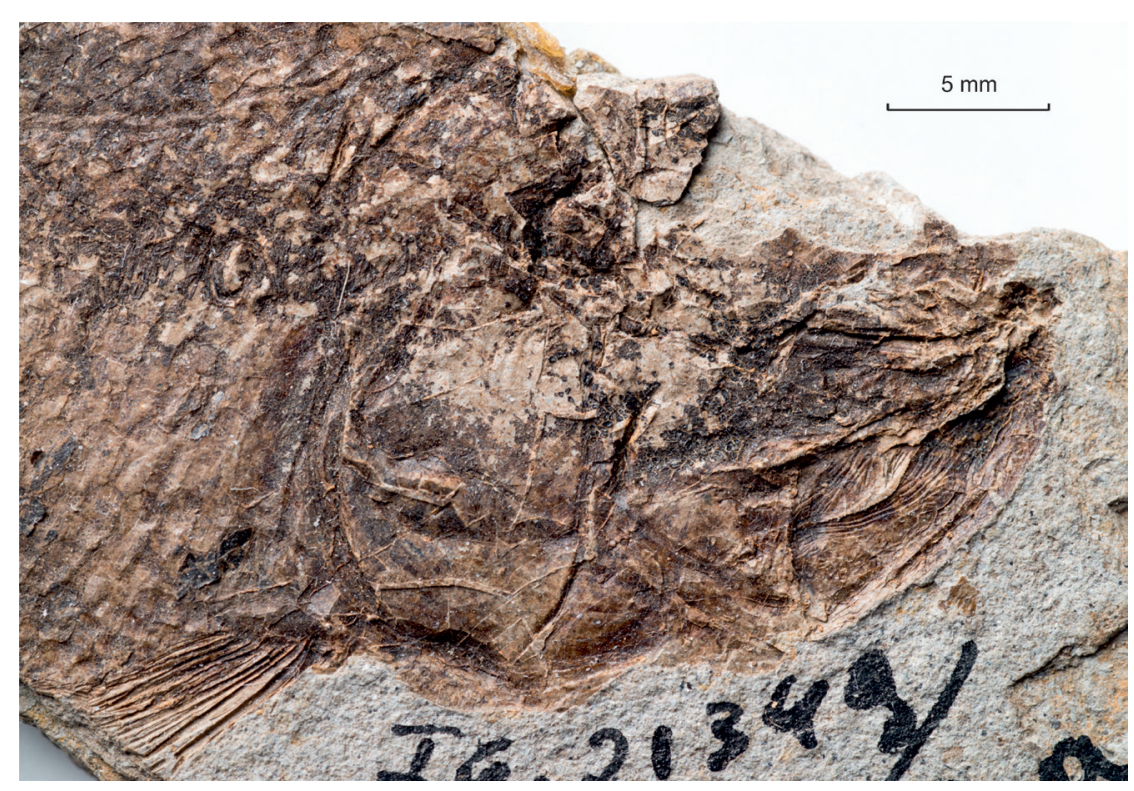




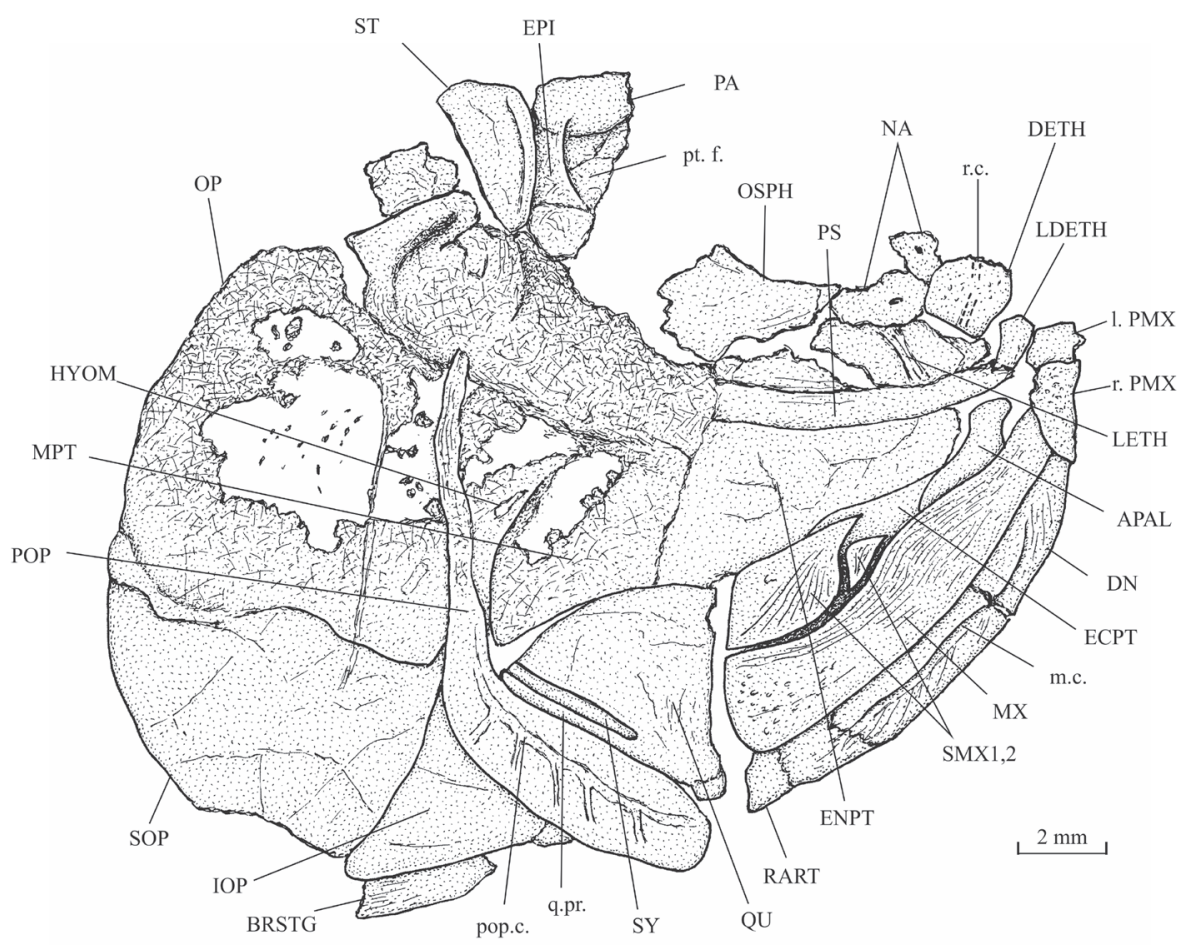

Figure 16. Luxembourgichthys friedeni (Delsate, 1999). Suspensorium of specimen IRSNB P 9695 (former IG $\left.21.349, \mathrm{~N}^{\circ} 384 \mathrm{~A}\right)$.

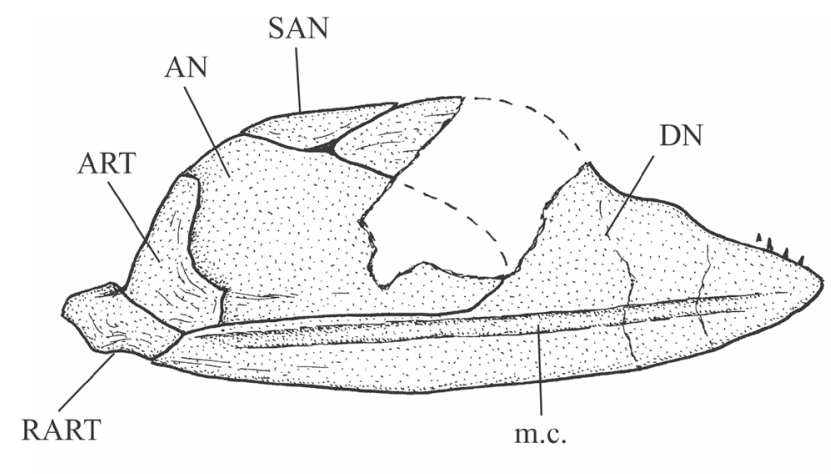

$1 \mathrm{~mm}$

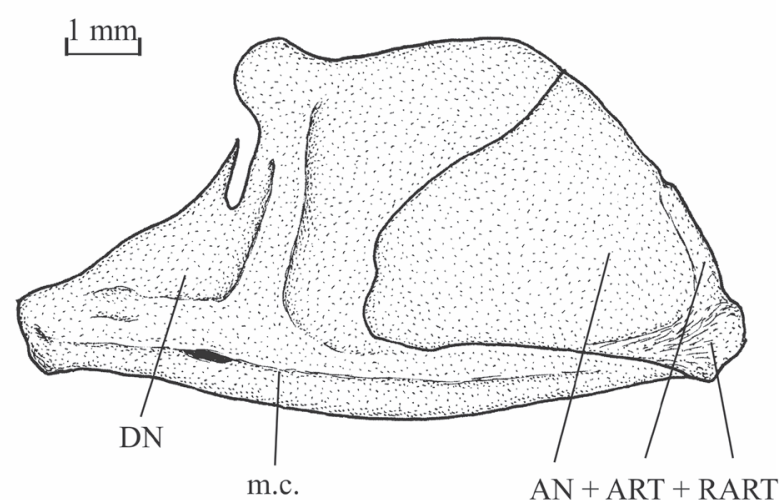

Figure 17. Comparison between the lower jaw of Luxembourgichthys friedeni (Delsate, 1999) [specimen IRSNB P 9697 (former I.G. $22.097, \mathrm{~N}^{\circ}$ 105-05), inner view] (left) and of Leptolepis normandica Nybelin, 1972 [specimen IRSNB P 9698 (former I.G. 21.349 Nº 67.05), external view] (right).

Figure 18. Luxembourgichthys friedeni (Delsate, 1999). Pectoral girdle of holotype MNHNL N ${ }^{\circ}$ TU 988 A (left) and of paratype

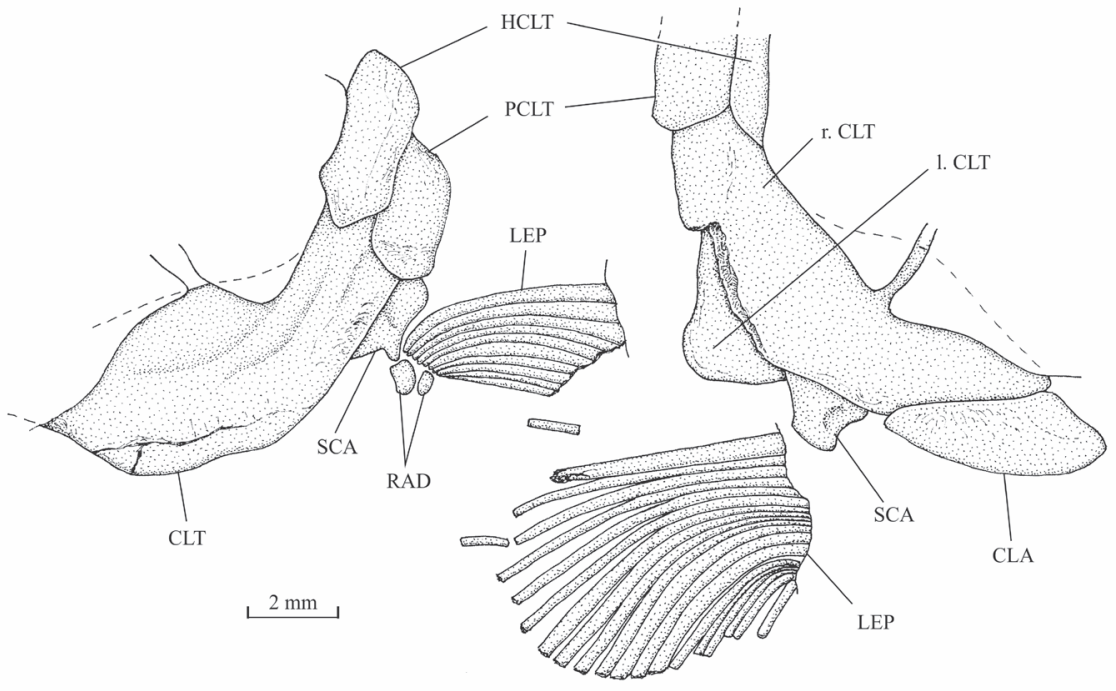

MNHNL Nº TU 988 B (right). 
a large triangular bone partly covered by the preopercle. The gular plate is large and triangular. The branchiostegal series is well preserved on the holotype. There are 10 branchiostegal rays. The first two ones are very short and broad. The others are narrow but progressively longer.

\section{2. - The hyoïdeo-branchial skeleton}

The anterior ceratohyal is pierced by a small beryciform fenestra (Delsate, 1999c, fig. 12). The branchial skeleton is unknown.

\section{3. - The girdles (Figs 18, 19)}

The pectoral girdle is rather well preserved on the holotype and paratype. The posttemporal is triangular and deeper than

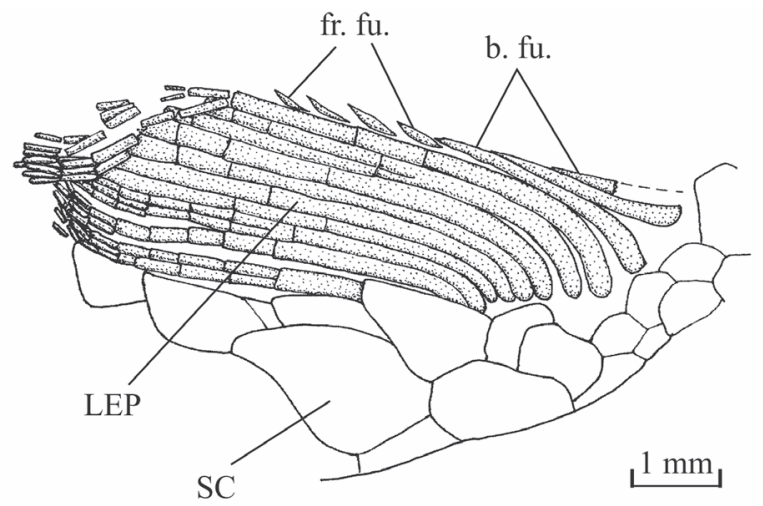

Figure 19. Luxembourgichthys friedeni (Delsate, 1999). Right ventral fin of paratype MNHNL $\mathrm{N}^{\circ} \mathrm{TU} 988 \mathrm{~B}$. long. The hypercleithrum (= supracleithrum) is rather narrow. The cleithrum is a broad bone, not very elongate and with its dorsal and ventral branches of almost the same length. A postcleithrum is located just behind the hypercleithrum. A large clavicle is visible on the paratype. The scapula and coracoid are fused in a single piece on which the pectoral fin articulates. Two small pectoral radials are preserved on the holotype. The most complete pectoral fin is shown on the paratype. There are 19 rays but their distal parts are lost. As seen on holotype, paratype and specimens MNHNL $\mathrm{N}^{\circ} \mathrm{TU}$ 763 and IRSNB P 9694 A, the first pectoral ray does not bear any fringing fulcra.

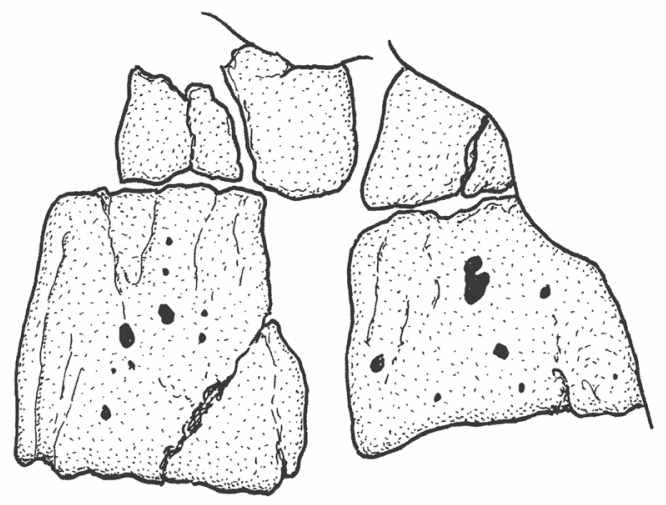

$1 \mathrm{~mm}$

Figure 20. Luxembourgichthys friedeni (Delsate, 1999). Two abdominal vertebral centra of specimen MNHNL $\mathrm{N}^{\circ} \mathrm{TU} 763$.

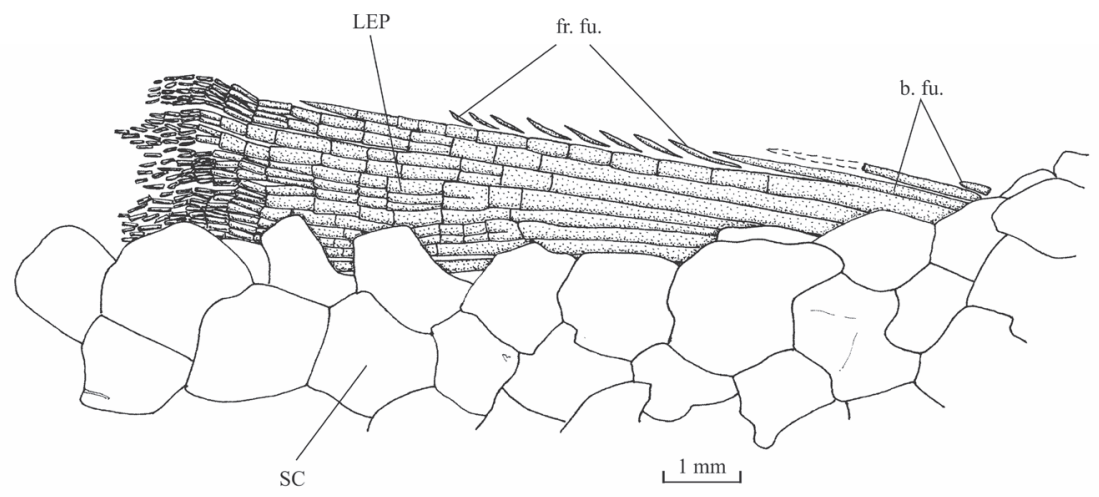

Figure 21. Luxembourgichthys friedeni (Delsate, 1999). Dorsal fin of paratype $\mathrm{MNHNL} \mathrm{N}^{\circ} \mathrm{TU} 988 \mathrm{~B}$.
Figure 22. Luxembourgichthys friedeni (Delsate, 1999). Anal fin of paratype $\mathrm{MNHNL} \mathrm{N}^{\circ} \mathrm{TU} 988 \mathrm{~B}$.

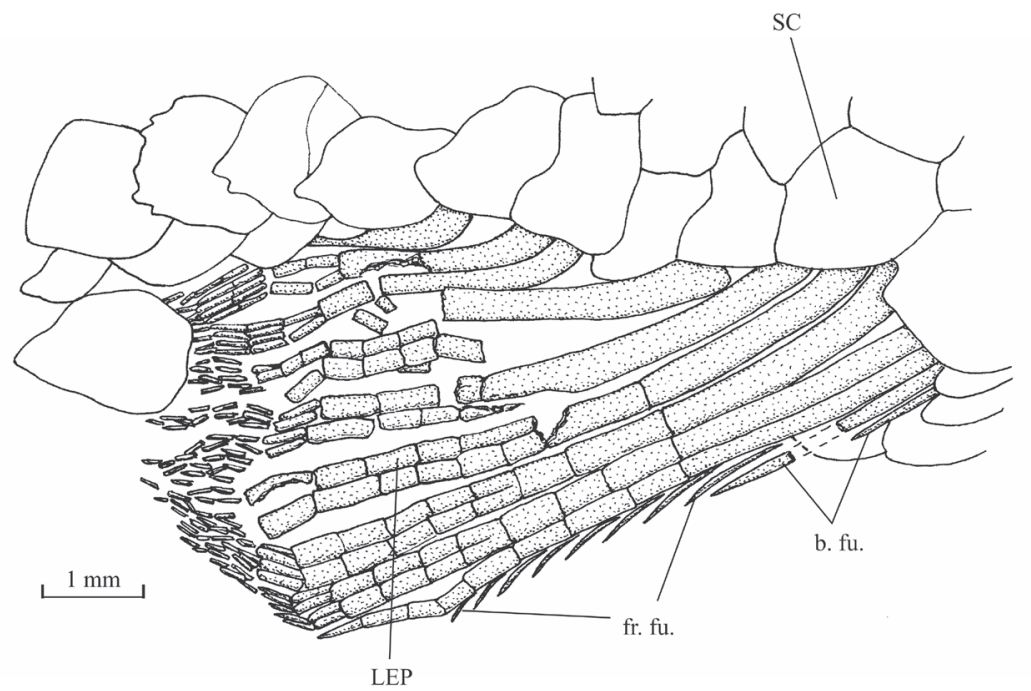




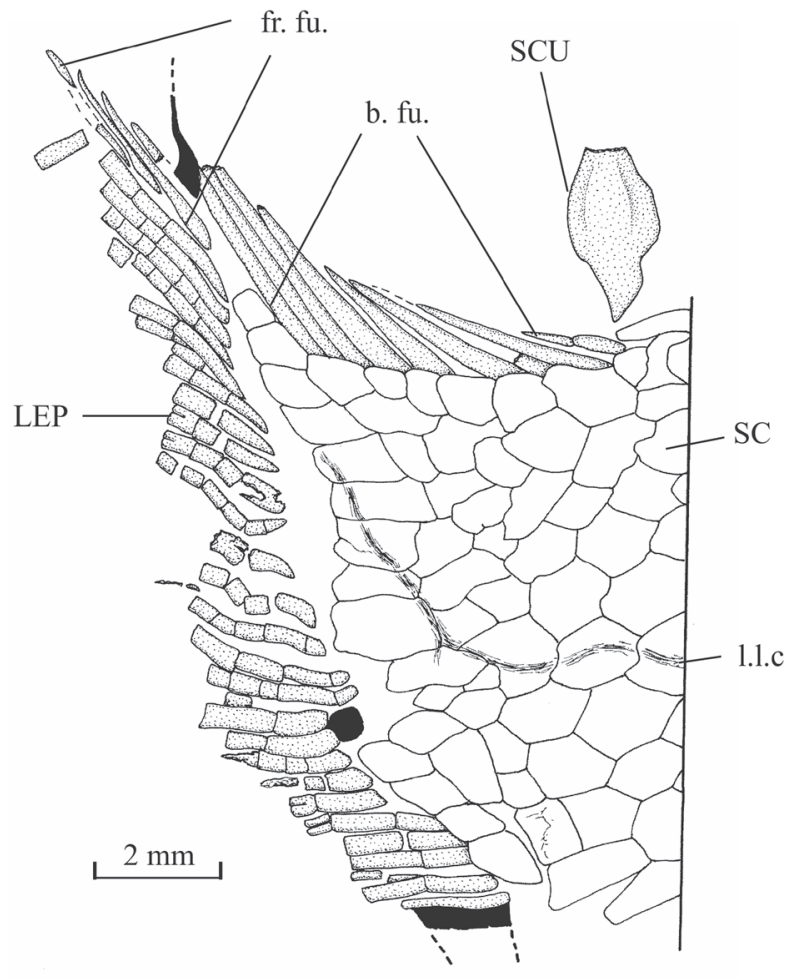

Figure 23. Luxembourgichthys friedeni (Delsate, 1999). Part of the caudal fin of paratype MNHNL N TU $988 \mathrm{~B}$.

The pelvic girdle is located before the level of the dorsal fin origin. The pelvic bones are not visible. They are always covered by the scales. The right ventral fin is complete and well visible on the paratype. It is a short fin that begins with 3 basal fulcra followed by 9 segmented and branched rays. There are 4 small fringing fulcra along the first ray but the series seems incomplete. Delsate (1999c, p. 158) mentions a specimen with around 15 rays (probably including the basal fulcra) on the ventral fin.

\section{4. - The axial skeleton (Fig. 20)}

The vertebrae are generally hidden by the scales and it is not possible to determine the exact number of vertebral elements that compose the axial skeleton. A few vertebrae are however visible. They are thick bony rings that surround the notochord. The separation between the dorsal and the ventral parts of these centra sometimes is preserved. The lateral faces are slightly ornamented with a few scarce and very small alveoli. This weakly marked ornamentation probably is due to the presence of autocentra associated to the chordacentra. In some crushed vertebrae, at least two bony layers are visible. That reinforces the hypothesis of the presence of autocentra surrounding at least partly the chordacentra.

\section{5. - The dorsal and anal fins (Figs 21, 22)}

The dorsal and anal fins are lost on the holotype but well preserved on the paratype. However, the pterygiophores are hidden by the scales.

The dorsal fin is deeper than the anal one but has a shorter insertion. The fin is located on the posterior half of the body. Its origin is posterior to that of the ventral fins and anterior to that of the anal fin. In the paratype, the fin begins by 3 basal fulcra followed by 8 segmented rays. The first basal fulcrum is very small. The two others are longer. The first ray is pointed and the seven other rays are branched. The first ray also is a little shorter than the immediately following rays. The anterior border of the first ray bears a series of 8 small fringing fulcra. Delsate (1999c, p. 158) describes a specimen with 12 rays (once again probably including the basal fulcra) in the dorsal fin.

The anal fin of the paratype is formed by 2 basal fulcra and 9 segmented rays. The first ray is pointed and a little shorter than the following eighth branched rays. There is a series of 8 small fringing fulcra along the anterior border of the first ray.

\section{6. - The caudal skeleton (Fig. 23)}

The caudal skeleton is hidden by the scales in all the available specimens with the tail region preserved. The caudal fin is never completely preserved. The paratype shows only the proximal extremity of the fin which counts 24 principal rays. On the dorsal border of the fish, the caudal fin is preceded by a large arrow head-shaped scute and begins by a series of at least 9 strong basal fulcra (= procurrent rays). There are a few long fringing fulcra along the first upper principal ray but the series is incomplete. Only one basal fulcrum is preserved in the lower lobe of the fin. The other lower basal and fringing fulcra are missing probably due to fossilisation.

\section{7. - Squamation (Fig. 24)}

The scale shape is variable, from circular to ovoid, from rhomboid to rectangular and sometimes completely irregular. They are not very thick. All the scales are covered by a thin layer of ganoine with a generally smooth surface. However, some rare scales bear a few granulations and some weakly developed ridges. The posterior border often is slightly serrated. But some scales exhibit a smooth posterior border. The scales of the dorsal ridge and of the ventral keel are rather small but not different in shape from those surrounded them. On the paratype, the ridge-tile scales following the dorsal fin bear a weakly marked median crest. In the abdominal part of the body, just below the lateral line, there is a rank of large
Figure 24. Luxembourgichthys friedeni (Delsate, 1999). Paratype MNHNL $\mathrm{N}^{\circ}$ TU 988 B. Scales from the dorsal region just before the dorsal fin (A), scales from the ventral region just before the ventral fin (B) and scales from the lateral line just before the anal fin level (C).
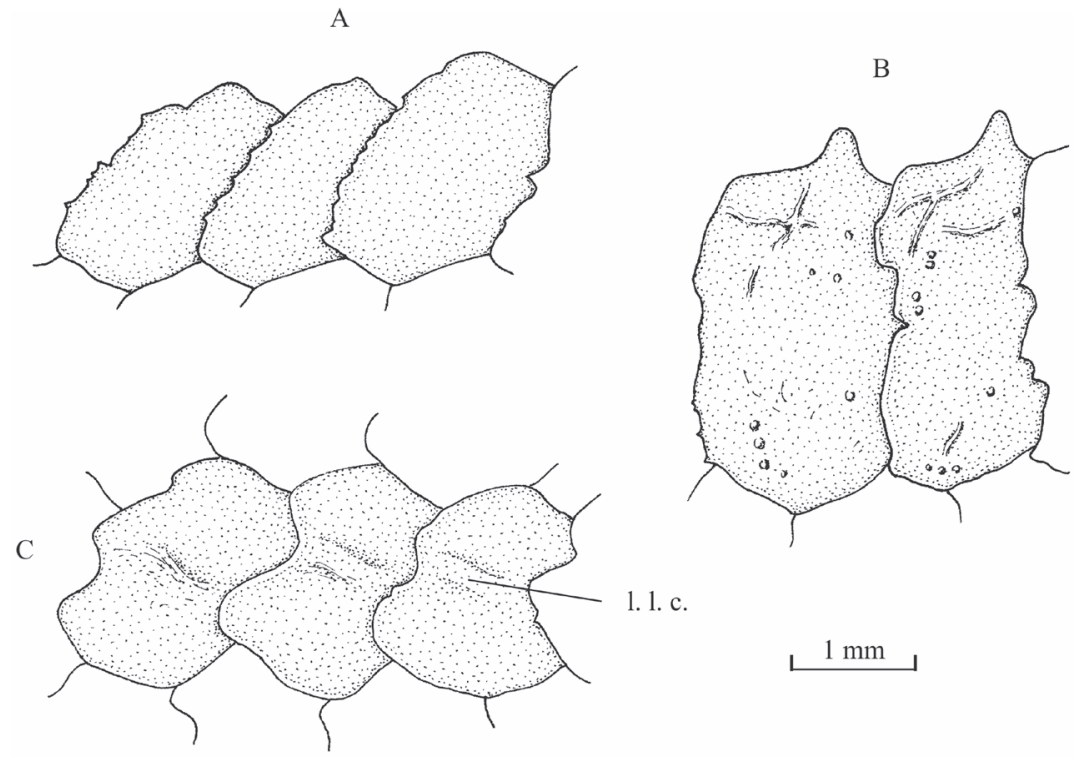
rectangular scales, deeper than long, which possess a welldeveloped peg-and-socket articulation system but most other scales seem devoid of the peg-and-socket articulation. The lateral line scales are more or less circular with the posterior border smooth but deeply notched. On the last caudal scales, the lateral line exhibits an upward curvature leading to the dorsal part of the caudal fin. On the ventral border of the fish, just before the pectoral and ventral fins, there are a few scales much smaller than the other scales.

\section{Discussion}

\subsection{Luxembourgichthys gen. nov. and Pholidophorus}

As previously mentioned, Delsate $(1999 \mathrm{a}, \mathrm{c})$ assigned Luxembourgichthys friedeni to the genus Pholidophorus, a taxon that has a long and complicated history.

Pholidophorus was erected by Agassiz (1832, p. 145) for two species from the Late Triassic of Austria, Pholidophorus latiusculus Agassiz, 1832 and Pholidophorus pusillus Agassiz, 1832. Ph. latiusculus, being the first mentioned, is thus the type-species of the genus (Taverne, 1981b, p. 55; Arratia, 2000 , p. 118). Numerous other species were attributed to Pholidophorus during the $19^{\text {th }}$ and $20^{\text {th }}$ centuries.

A first attempt to better define the genus and its putative species was carried out by Woodward (1895, pp. 447-478). However, the new generic diagnosis given by him did not rest on apomorphies but on general characters and plesiomorphies. Moreover, he considered Pholidophorus bechei Agassiz, 1837 and not Pholidophorus latiusculus as the type-species of the genus. In a later paper Woodward (1941) did not really improve his previous diagnosis as his new definition of the genus was only based on the species Pholidophorus bechei.

A half-century later, Zambelli (1986, pp. 7-9) restricted Pholidophorus to only two species, Pholidophorus latiusculus and Pholidophorus bechei. Arratia (2000, pp. 134-135) has confirmed this point of view, although specifying that $P h$. latiusculus and not $P h$. bechei is the type-species of the genus. She also introduced for the first time a cladistic definition of Pholidophorus.

More recently, Arratia (2013, p. 15) has re-studied the osteology and has provided a new emended diagnosis for Pholidophorus. She has maintained in the genus only two species, Pholidophorus latiusculus, the poorly known typespecies, and Pholidophorus gervasuttii Zambelli, 1980. She has rejected the other species ever ranged in Pholidophorus, notably the well-known "Pholidophorus" bechei that is referred to the new genus Dorsetichthys Arratia, 2013 and is no longer included in the family Pholidophoridae.

Specimens of Ph. latiusculus are rare and all show badly crushed skulls. So the new diagnosis is principally based on Ph. gervasuttii that is represented by more and better preserved samples. This new definition mentions only one autapomorphy for the genus. The anterior extremities of the frontals (called "parietals" in Arratia's monograph), that separate the two nasals, are elongated and very narrow, with a width of about one-fifth or one-sixth of the postorbital skull width (Arratia, 2013, p. 15; node C1b, character 5[1]). That is one of the most striking characters of the genus.

It is to be noted that, in the phylogenetic hypothesis proposed by Arratia (2013), Pholidophorus gervasuttii shares with Knerichthys and Pholidorhynchodon a few characters (her node C1d) not known in Pholidophorus latiusculus. Such a paradoxical situation implies that the genus Pholidophorus, as understood now by Arratia, is paraphyletic, a fact that she willingly concedes (Arratia, 2013, pp. 116, 118). The only hope to obtain one day a more accurate diagnosis of Pholidophorus will depend on the possible future discovery of new and better preserved specimens of Pholidophorus latiusculus.

In Luxembourgichthys friedeni, the nasals meet on the midline. The frontals are largely separated from the dermethmoid and their anterior extremities are neither elongate nor acuminate. According to these characters, L. friedeni cannot be included in the genus Pholidophorus as now understood.

Moreover, all the known Pholidophoridae sensu stricto, including Pholidophorus, differ from L. friedeni by a series of other important characters (Arratia, 2013; Tintori et al., 2015; Taverne \& Capasso, 2015). These are : 1 . The skull roof bones are partially or totally fused; 2 . Dermethmoid (= rostral) bears distinct lateral processes; 3. Isolated lateral dermethmoids are missing; 4. Endocranium is weakly ossified and there is no bony supraoccipital; 5. The dental and the splenial regions of the dentary are separated by a well-marked crest; and 6. Quadrate is devoid of bony quadrate process. These osteological features clearly show that $L$. friedeni does belong neither to Pholidophorus nor to the family Pholidophoridae.

\subsection{The generic validity of Luxembourgichthys gen. nov.}

In Luxembourgichthys friedeni, the posttemporal fossa is surrounded by the pterotic, the parietal and the epiotic. This fossa is not located on the rear of the skull, as usual, but on its lateral wall. No other genus or species ever reported to the "Pholidophoriformes" or to the Pholidophoridae (sensu Arratia, 2013) exhibits a laterally positioned posttemporal fossa. This extremely rare osteological character of $L$. friedeni amply justifies the peculiar generic status of this fossil fish.

\subsection{Luxembourgichthys gen. nov. within "Pholidophoriformes"}

At least, three characters of Luxembourgichthys friedeni militate for a systematic position within the most advanced members of the heterogeneous order "Pholidophoriformes" and thus very close to the "classical" Jurassic teleosts with cycloid scales, such as Pholidolepis dorsetensis Nybelin, 1966 and Leptolepis coryphaenoides (Bronn, 1830).

L. friedeni exhibits a beryciform fenestra piercing its anterior ceratohyal. The presence of such a fenestra is an apomorphic character that appears for the first time in the archaic Jurassic teleosts with cycloid scales, such as Leptolepis coryphaenoides (Rayner, 1937, fig. 6), Leptolepis normandica Nybelin, 1962 (pers. obs., L.T.), Tharsis dubius (De Blainville, 1818) (Nybelin, 1974, figs 24, 25), Leptolepides sprattiformis (De Blainville, 1818) (ibid., 1974, fig. 31B-E; Taverne, 1981a, fig. 6; Arratia, 1997, figs 42A, B, 43A) or Paraclupavus caheni De Saint-Seine \& Casier, 1962 (Taverne, 1975, fig. 7). However, in those fishes, the beryciform fenestra is already more enlarged than in Pholidophorus friedeni. On the contrary, the anterior ceratohyal remains unfenestrated in most "Pholidophoriformes", i.e., the Catervariolidae (Taverne, 2011b, fig. 34), the Ankylophoridae sensu Taverne, 2011 (Biese, 1927, fig. 8; Taverne, 2011a, fig. 10), the Ichthyokentemidae (Griffith \& Patterson, 1963, fig. 11), the Pholidophoridae sensu stricto (Arratia, 2013, fig. 15), Dorsetichthys ("Pholidophorus") bechei (Nybelin, 1966, pl. 3, fig. 5) and Pleuropholidae (L.T. pers. obs. on the Congolese material from the Stanleyville Formation).

The presence of autocentra associated with the chordacentra in L. friedeni is another feature indicating close relationship with the "classical" teleosts, that is to say those with cycloid scales. Indeed, this character is often considered as an autamorphy shared by Leptolepis coryphaenoides and the more specialized teleosts (see for instance Arratia et al., 2001, p. 147).

The scales of $L$. friedeni are ganoid but not very thick. Most of them have already lost the peg-and-socket articulation and some of them become ovoid or circular, a shape close to that of the classic teleostean cycloid scales.

\subsection{Luxembourgichthys gen. nov. and the Osteoglossomorpha}

Luxembourgichthys friedeni and the Osteoglossomorpha share two peculiar characters that occur rarely within teleost fishes. As previously described, L. friedeni exhibits a broad and laterally positioned posttemporal fossa. Such a situation is extremely rare within teleosts. Generally, the fossa opens on 
the rear of the skull. This peculiar morphology is also present in the Osteoglossomorpha (Taverne, 1968, 1977, 1978; among others), one of the most primitive superorders among the "classical" teleosts. Moreover, in L. friedeni, the parietal forms the dorsal margin and the upper part of the lateral margin of this fossa. Such substantial participation of the parietal in the borders of the posttemporal fossa also is exceptional within teleosts but, once again, is known in some Osteoglossomorpha (Greenwood, 1970, figs 1-4; Taverne, 1977, figs 3, 4, 94, 95, 104, 1978, figs 31, 32, 34; Taverne \& Capasso, 2012, fig. 4; among others). In some cases within "Pholidophoriformes", the parietal reaches the dorsal border of the fossa but only in a very restricted area (Griffith \& Patterson, 1963, fig. 4; Patterson, 1975, figs 56, 59-61, 82) and never more.

We have also seen that the lateral dermethmoids remain independent from the dermethmoid (= rostral) in L. friedeni. In Leptolepis coryphaenoides and in most "classical" teleosts, the lateral dermethmoids are fused to the dermethmoid, forming a compound bone (Patterson, 1975; Taverne, 2011a, fig. 20 D). However, independent lateral dermethmoids are preserved in some rare teleost lineages. That is the case in at least two osteoglossomorph families, the Hiodontidae (Taverne, 1977, fig. 7 [the lateral dermethmoids are called capsular ethmoids]) and the Osteoglossidae (Taverne et al., 2009, fig. 3).

\section{Acknowledgments}

We greatly thank Dr. Robert Weis, from the Section of Paleontology of the National Museum of Natural History (Grand Duchy of Luxembourg), for the loan of the type material of Luxembourgichthys friedeni, and Dr. Dominique Delsate (Battincourt) for his assistance in delivering the study material. We are also grateful to $\mathrm{M}$. Adriano Vandersypen, M. Thierry Hubin and M. Wilfrid Miseur (KBIN-IRSNB) for their technical assistance. Special thanks are due to Matt Friedman (Museum of Paleontology, Department of Earth and Environmental Science, University of Michigan, Ann Arbor) and Guang-Hui Xu (Institute of Vertebrate Paleontology and Paleoanthropology, Beijing) whose reviews improved the quality of the paper.

\section{References}

Agassiz, L., 1832. Untersuchungen über die fossilen Fische der LiasFormation. Jahrbuch für Mineralogie, Geognosie, Geologie und Petrefaktenkunde, 3, 139-149.

Arratia, G., 1997. Basal teleosts and teleostean phylogeny. Palaeo Ichthyologica, 7, 1-168.

Arratia, G., 2000. New teleostean fishes from the Jurassic of southern Germany and the systematic problems concerning the "pholidophoriforms". Paläontologische Zeitschrift, 74/1-2, 113-143.

Arratia, G., 2013. Morphology, taxonomy, and phylogeny of Triassic pholidophorid fishes (Actinopterygii, Teleostei). Journal of Vertebrate Paleontology, 33, Supplement to Nr 6, Memoir 13, 1-138.

Arratia, G., Schultze, H.P. \& Casciotta, J., 2001. Vertebral column and associated elements in Dipnoans and comparison with other fishes: development and homology. Journal of Morphology, 250, 101-172.

Belanger, I., Delsate, D., Ghysel, P., Laloux, M. \& Boulvain, F., 2002. Carte géologique de Wallonie : Saint-Léger - Messancy 71/3-4, Musson - Le Fays 71/7-8, Houwald 72/1. 1/25 000. Namur, Ministère de la Région wallonne, Direction générale des ressources naturelles et de l'environnement, avec une notice explicative de $35 \mathrm{p}$.

Biese, W., 1927. Ueber einige Pholidophoriden aus den lithographischen Schiefern Bayerns. Neues Jahrbuch für Mineralogie, Geologie und Paläontologie, 58, 50-100.

Boulvain, F., Belanger, I., Delsate, D., Ghysel, P., Godefroit, P., Laloux, M., Monteyne, R. \& Roche, M., 2001. Triassic and Jurassic lithostratigraphic units (Belgian Lorraine). In Bultynck, P. \& Dejonghe, L. (eds), Lithostratigraphic scale of Belgium. Geologica Belgica, 4/1-2, 113-119.

Delsate, D., 1999a. L'ichthyofaune du Toarcien luxembourgeois. Cadre général et catalogue statistique. Travaux Scientifiques du Musée National d'Histoire Naturelle du Luxembourg, 31, 1-101.

Delsate, D., 1999b. Haasichthys michelsi, nov. gen., nov. sp., un nouveau Pachycormiforme (Osteichthyes, Actinopterygii) du Toarcien inférieur (Jurassique) luxembourgeois. Travaux Scientifiques du Musée National d'Histoire Naturelle du Luxembourg, 32, 87-140.
Delsate, D., 1999c. Un Pholidophoridae nouveau (Osteichthyes, Actinopterygii) du Toarcien (Jurassique inférieur) luxembourgeois. Travaux Scientifiques du Musée National d'Histoire Naturelle du Luxembourg, 32, 141-205.

Greenwood, P.H., 1970. On the genus Lycoptera and its relationship with the family Hiodontidae (Pisces, Osteoglossomorpha). Bulletin of the British Museum (Natural History), Zoology, 19/8, 259-285.

Griffith, J. \& Patterson, C., 1963. The structure and relationships of the Jurassic fish Ichthyokentema purbeckensis. Bulletin of the British Museum (Natural History), Geology, 8/1, 1-43.

Monari, S., Valentini, M. \& Conti, M.A., 2011. Earliest Jurassic patellogastropod, vetigastropod, and neritimorph gastropods from Luxembourg with considerations on the Triassic-Jurassic faunal turnover. Acta Palaeontologica Polonica, 56/2, 349-384.

Nybelin, O., 1966. On certain Triassic and Liassic representatives of the family Pholidophoridae s. str. Bulletin of the British Museum (Natural History), Geology, 11/8, 351-432.

Nybelin, O., 1974. A revision of the leptolepid fishes. Acta Regiae Societatis Scientiarum et Litterarum Gothoburgensis, Zoologica, 9, 1-202.

Patterson, C., 1973. Interrelationships of holosteans. Zoological Journal of the Linnean Society, 53 (Supplement 1), 233-305.

Patterson, C., 1975. The braincase of pholidophorid and leptolepid fishes, with a review of the actinopterygian braincase. Philosophical Transactions of the Royal Society of London, series B, Biological Sciences, 269/899, 275-579.

Rayner, D.H., 1937. On Leptolepis bronni Agassiz. Annals and Magazine of Natural History, series 10, 19/2, 46-74.

Schintgen, T., 2015. Exploration for deep geothermal reservoirs in Luxembourg and the surroundings - perspectives of geothermal energy use. Geothermal Energy 3/ 9, 30 p.

Schintgen, T. \& Förster, A., 2013. Geology and basin structure of the Trier-Luxembourg Basin - implications for the existence of a buried Rotliegend graben. Zeitschrift der Deutschen Gesellschaft für Geowissenschaften, 164/4, 615-637.

Taverne, L., 1968. Ostéologie du genre Gnathonemus Gill sensu stricto [Gnathonemus petersii (Gthr) et espèces voisines] (Pisces Mormyriformes). Annales du Musée Royal de l'Afrique Centrale, Tervuren, série in- $8^{\circ}$, Sciences Zoologiques, 170, 1-91.

Taverne, L., 1975. Étude ostéologique de Leptolepis caheni, téléostéen fossile du Jurassique supérieur (Kimméridgien) de Kisangani (exStanleyville, Zaïre) précédemment décrit dans le genre Paraclupavus. Revue de Zoologie Africaine, 89/4, 821-853.

Taverne, L., 1977. Ostéologie, phylogénèse et systématique des téléostéens fossiles et actuels du super-ordre des Ostéoglossomorphes. Première partie. Ostéologie des genres Hiodon, Eohiodon, Lycoptera, Osteoglossum, Scleropages, Heterotis et Arapaima. Académie Royale de Belgique, Mémoires de la Classe des Sciences, collection in- $8^{\circ}, 2^{\mathrm{e}}$ série, 42/3, 1-235.

Taverne, L., 1978. Ostéologie, phylogénèse et systématique des téléostéens fossiles et actuels du super-ordre des Ostéoglossomorphes. Deuxième partie. Ostéologie des genres Phareodus, Phareoides, Brychaetus, Musperia, Pantodon, Singida, Notopterus, Xenomystus et Papyrocranus. Académie Royale de Belgique, Mémoires de la Classe des Sciences, collection in- $8^{\circ}$, 2e série, 42/6, 1-213.

Taverne, L., 1981a. Ostéologie et affinités systématiques de Leptolepides sprattiformis (Pisces, Teleostei) du Jurassique supérieur de l'Europe. Annales de la Société Royale Zoologique de Belgique, 110/1, 7-28.

Taverne, L., 1981b. Les Actinoptérygiens de l'Aptien inférieur (Töck) d'Helgoland. Mitteilungen aus dem Geologisch-Paläontologischen Institut der Universität Hamburg, 51, 43-82.

Taverne, L., 2011a. Ostéologie et relations phylogénétique de Steurbautichthys («Pholidophorus ») aequatorialis gen. nov. (Teleostei, " Pholidophoriformes ») du Jurassique moyen de Kisangani, en République Démocratique du Congo. Bulletin de l'Institut Royal des Sciences Naturelles de Belgique, Sciences de la Terre, 81, 129-173.

Taverne, L., 2011b. Ostéologie et relations de Catervariolus (Teleostei, " Pholidophoriformes ») du Jurassique moyen de Kisangani (Formation de Stanleyville) en République Démocratique du Congo. Bulletin de l'Institut Royal des Sciences Naturelles de Belgique, Sciences de la Terre, 81, 175-212.

Taverne, L., 2011c. Ostéologie et relations de Ligulella (Halecostomi, Ligulelliformes nov. ord.) du Jurassique moyen de Kisangani (Formation de Stanleyville) en République Démocratique du Congo. Bulletin de l'Institut Royal des Sciences Naturelles de Belgique, Sciences de la Terre, 81, 213-233. 
Taverne, L., 2014a. Ostéologie et position systématique de Songanella callida (Teleostei, Catervarioliformes nov. ord.) du Jurassique moyen de Kisangani (Formation de Stanleyville, Calcaires de Songa) en République Démocratique du Congo. Geo-Eco-Trop, 37/1 (2013), $1-32$.

Taverne, L., 2014b. Osteology and relationships of Songaichthys luctacki gen. and sp. nov. (Teleostei, Ankylophoriformes ord. nov.) from the Middle Jurassic (Songa Limestones) of Kisangani (Democratic Republic of Congo). Geo-Eco-Trop, 37/1 (2013), 3352.

Taverne, L. \& Capasso, L., 2012. Osteology and relationships of Prognathoglossum kalassyi gen. and sp. nov. (Teleostei, Osteoglossiformes, Pantodontidae) from the marine Cenomanian (Upper Cretaceous) of En Nammoura (Lebanon). Cybium, 36/4, 563-574.

Taverne, L. \& Capasso, L., 2015. Osteology and relationships of Ceneichthys zambellii gen. and sp. nov. (Teleostei, Pholidophoridae) from the Late Triassic of northern Italy. Bollettino del Museo Civico di Storia Naturale, Geologia Paleontologia Preistoria, 39, 13-26.

Taverne, L., Kumar, K. \& Rana, R.S., 2009. Complements to the study of the Indian Paleocene osteoglossid fish genus Taverneichthys (Teleostei, Osteoglossomorpha). Bulletin de l'Institut Royal des Sciences Naturelles de Belgique, Sciences de la Terre, 79, 155-160.

Tintori, A., Zuoyu, S., Peigang, N., Lombardo, C., Dayong, J. \& Motani, R., 2015. Oldest stem Teleostei from the Late Ladinian (Middle Triassic) of southern China. Rivista Italiana di Paleontologia e Stratigrafia, 121/3, 285-296.

Van den Bril, K. \& Swennen, R., 2008. Sedimentological control on carbonate cementation in the Luxembourg Sandstone Formation. Geologica Belgica, 12/1-2, 3-23.

Woodward, A.S., 1895. Catalogue of the fossil fishes in the British Museum (Natural History). Part III. Trustees of the British Museum (Natural History), London, I-XXXIX + 1-544.

Woodward, A.S., 1941. The Mesozoic ganoid fishes of the genus Pholidophorus Agassiz. Annals and Magazine of Natural History, series 11, 8/8, 88-91.

Zambelli, R., 1975. Note sui Pholidophoriformes. I. Parapholidophorus nybelini gen. n. sp. n. Istituro Lombardo, Accademia di Scienze e Lettere, Rendiconti, Classe di Scienze (B), $109,3-49$.

Zambelli, R., 1986. Note sui Pholidophoriformes. VI contributo. Pholidophorinae subfamiglia nuova del Triassico Superiore. Revista del Museo Civico di Scienze Naturali "Enrico Caff”, Bergamo, 10, $1-32$. 